\title{
A systematic review of the characteristics and needs of older prisoners
}

\begin{tabular}{|r|l|}
\hline Journal: & Journal of Criminal Psychology \\
\hline Manuscript ID & JCP-06-2020-0023.R1 \\
\hline Manuscript Type: & Research Paper \\
\hline Keywords: & $\begin{array}{l}\text { elderly prisoner, older prisoner, characteristics, ageing prisoners, ageing } \\
\text { in prison, prisoners }\end{array}$ \\
\hline \multicolumn{2}{|l}{} \\
\end{tabular}

SCHOLARONE $^{\text {m }}$
Manuscripts 
MANUSCRIPT DETAILS

TITLE: A systematic review of the characteristics and needs of older prisoners

ABSTRACT:

The older prisoner population is growing faster than the older general population and placing a strain on prisons. Much of the existing literature focusses on the healthcare needs of, or in-prison initiatives for, older prisoners. Typically, these are responsive and lacking an evidence-based understanding of the characteristics and needs of this group. There is a need to review and understand what the existing evidence base concludes about the needs of this population.

This paper presents a systematic review of the existing literature on the needs and characteristics of older people in contact with the criminal justice system. After a thorough search and selection process, 21 papers, from 2002 onwards, were included in the final analysis. The review process was structured through PICOs and reported using PRISMA.

The contradictions within the existing evidence base make it difficult to reach firm conclusions about the needs and characteristics of older prisoners. What is clear from the existing research are the relatively high levels of need. There is also some consensus that where older people commit homicide the victim is likely to be an intimate partner. Overall, there a need for consistent recording and reporting of characteristics and demographics and more systematic study design.

CUST_RESEARCH_LIMITATIONS/IMPLICATIONS_(LIMIT_100_WORDS) :No data available.

CUST_PRACTICAL_IMPLICATIONS_(LIMIT_100_WORDS) :No data available.

CUST_SOCIAL_IMPLICATIONS_(LIMIT_100_WORDS) :No data available.

This paper has highlighted the key findings and limitations in the existing literature. Future research should make use of secondary official data sources to provide a clearer understanding of the characteristics of this group, their routes to prison, their needs, and challenges they present. 


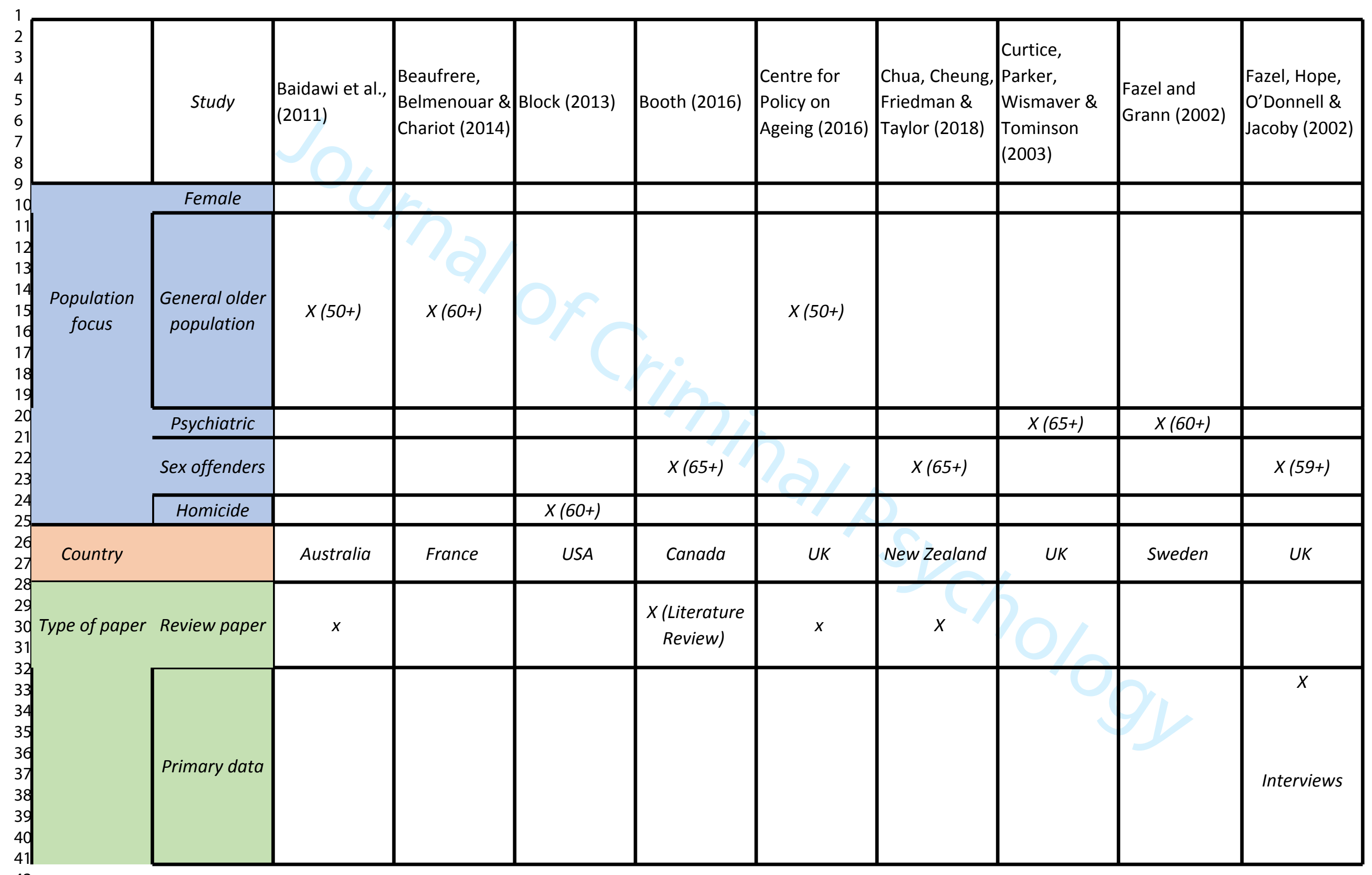




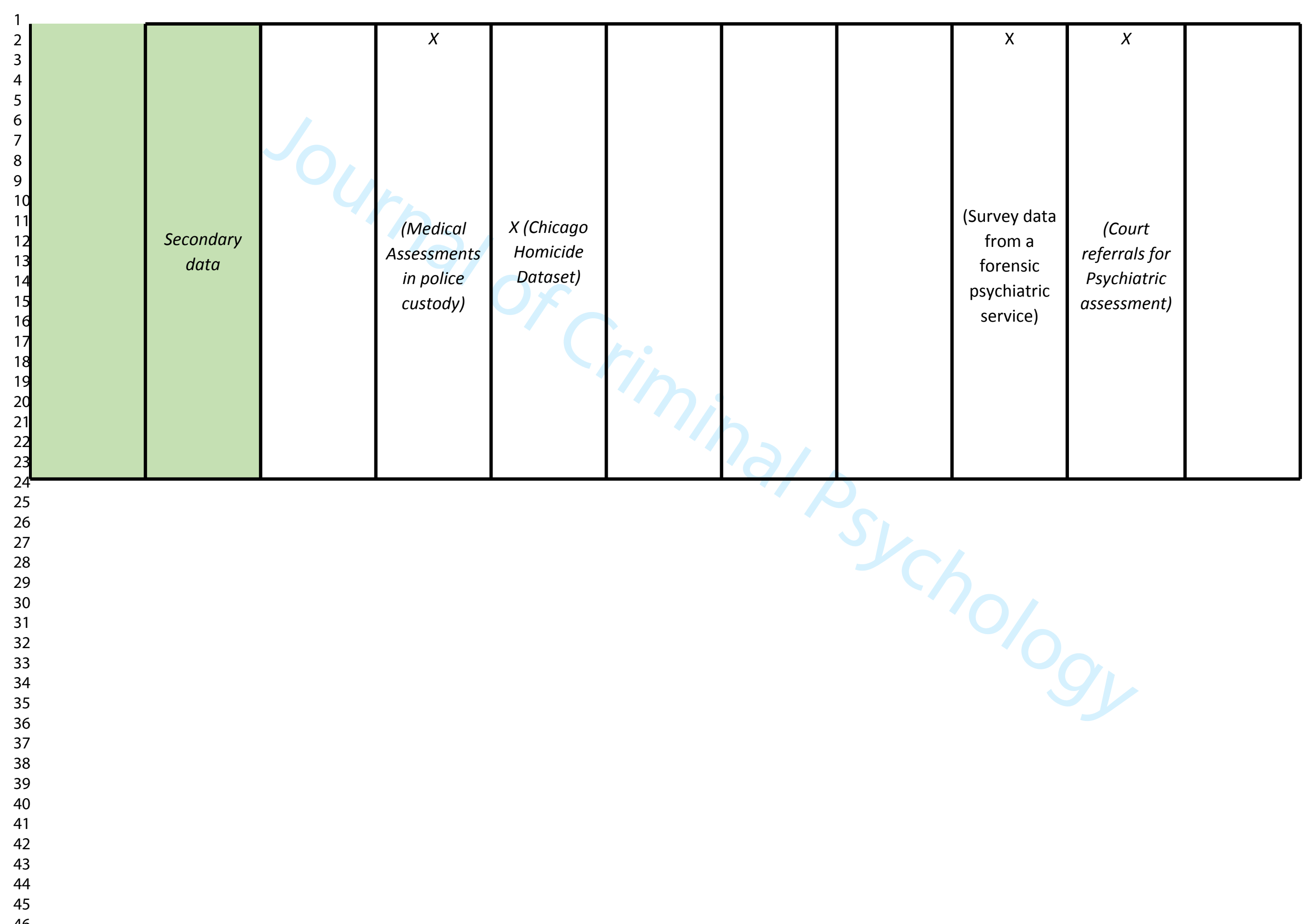




\begin{tabular}{|c|c|c|c|c|c|c|c|c|c|c|}
\hline $\begin{array}{l}\text { Fazel, O’Donnell, } \\
\text { Hope, Gulati \& } \\
\text { Jacoby (2007) }\end{array}$ & $\mid \begin{array}{l}\text { Feldmeyer \& } \\
\text { Steffensmeier } \\
(2007)\end{array}$ & $\begin{array}{l}\text { Greene \& } \\
\text { Gibson (2013) }\end{array}$ & Gross (2007) & Hunt et al., (2010) & $\begin{array}{l}\text { Overshott et } \\
\text { al., (2012) }\end{array}$ & $\begin{array}{l}\text { Putkonen et } \\
\text { al., (2010) }\end{array}$ & \begin{tabular}{|l} 
Reutens, \\
Nielssen \& \\
Large (2015)
\end{tabular} & $\begin{array}{l}\text { Rodriguez, } \\
\text { Boyce \& } \\
\text { Hodges } \\
\text { (2017) }\end{array}$ & $\begin{array}{l}\text { Stanback \& } \\
\text { king- } \\
\text { kallimanis } \\
(2011)\end{array}$ & $\begin{array}{l}\text { Willimans \& } \\
\text { Rikard (2005) }\end{array}$ \\
\hline 0 & & 1 & & & & & & & & $x(45+)$ \\
\hline $\begin{array}{l}4 \\
5 \\
6\end{array}$ & $x(55+)$ & $x(50+)$ & $x(55+)$ & & & & & & & \\
\hline 9 & & & & & $\overline{15}$ & & & & & \\
\hline$x(59+)$ & & & & & & & & $x(50+)$ & & \\
\hline Sweden & USA & USA & USA & England and Wales & $\begin{array}{l}\text { England and } \\
\text { Wales }\end{array}$ & Finland & Australia & Australia & USA & USA \\
\hline 9 & & $x$ & $x$ & & & & & & & \\
\hline 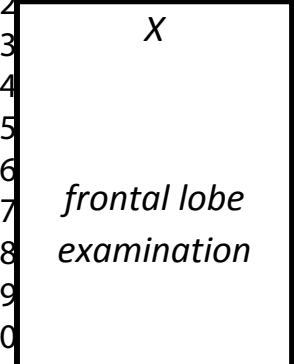 & & & & & & & & \begin{tabular}{|c|}
$x$ \\
neuropsychol \\
ogical study of \\
first time \\
older sex \\
offenders
\end{tabular} & & $\begin{array}{c}x \\
\text { interviews } \\
\text { with federal } \\
\text { bureau of } \\
\text { prisons }\end{array}$ \\
\hline
\end{tabular}




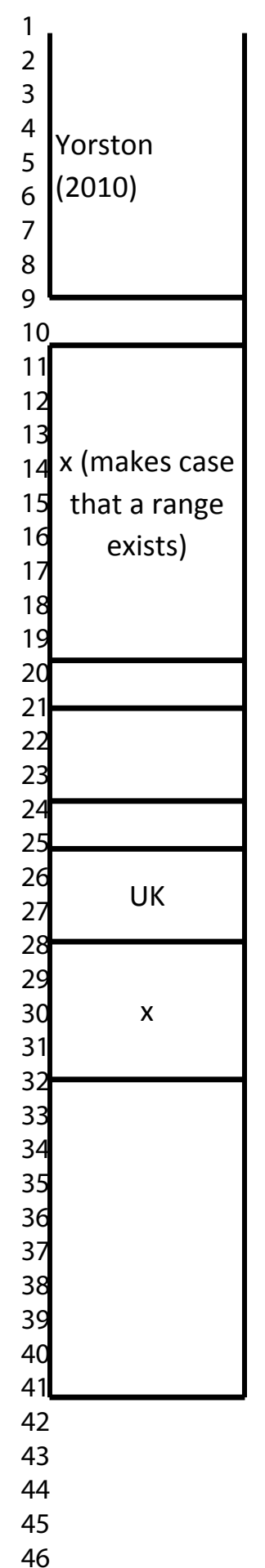




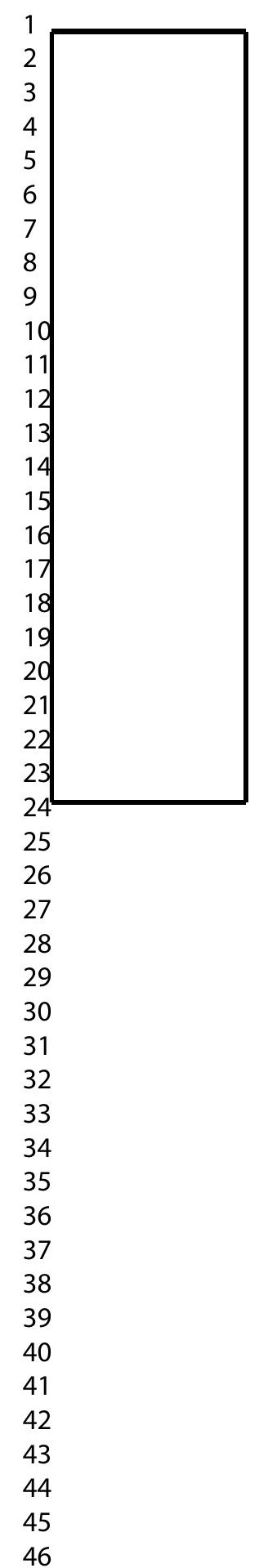




\title{
A systematic review of the characteristics and needs of older prisoners
}

\author{
Abstract \\ Purpose \\ The older prisoner population is growing faster than the older general population and placing a \\ strain on prisons. Much of the existing literature focusses on the healthcare needs of, or in-prison \\ initiatives for, older prisoners. Typically, these are responsive and lacking an evidence-based \\ understanding of the characteristics and needs of this group. There is a need to review and \\ understand what the existing evidence base concludes about the needs of this population. \\ Design/methodology/approach
} This paper presents a systematic review of the existing literature on the needs and characteristics of older people in contact with the criminal justice system. After a thorough search and selection process, 21 papers, from 2002 onwards, were included in the final analysis. The review process was structured through PICOs and reported using PRISMA.

Findings

The contradictions within the existing evidence base make it difficult to reach firm conclusions about the needs and characteristics of older prisoners. What is clear from the existing research are the relatively high levels of need. There is also some consensus that where older people commit homicide the victim is likely to be an intimate partner. Overall, there a need for consistent recording and reporting of characteristics and demographics and more systematic study design.

Originality/value

This paper has highlighted the key findings and limitations in the existing literature. Future research should make use of secondary official data sources to provide a clearer understanding of the characteristics of this group, their routes to prison, their needs, and challenges they present.

\section{Keywords}

\section{Elderly Prisoner; Older Prisoner; Characteristics; Older Offender}

This research did not receive any specific grant from funding agencies in the public, commercial, or not-for-profit sectors.

\subsection{Introduction}




\subsection{The ageing prison population: an international issue}

Across the world, the prison population is ageing. In the United States, for example, the number of prisoners over age 55 increased by 181\% between 2000 and 2010 (Bureau of Justice Statistics 19902010). This is compared to an increase in the overall US prison population of $17 \%$ during the same time period (Williams, Goodwin, Baillargeon, Ahalt \& Walter, 2012). The most recent data show that 19\% of the current US prison population are 50 years and over (Federal Bureau of Prisons, 2019). The same pattern appears to be emerging in the Asia Pacific region: for example, the Philippines saw the older prisoner group increase from 28\% to 43\% of the prison population between 2002 and 2014 (Bureau of Corrections \& Philippine Statistics Authority, 2015). Baidawi et al. (2011) highlight that in Australia the older prisoner population growth has been much greater than the general older population growth, a pattern mirrored in many other countries. In 2009, Japan had one of the highest proportions of older people in prison (Naikakufu, 2009; Ishihara \& Kempf-Leonard, 2009) and in 2016 people over 50 years contributed 35\% of new male prisoners and $39 \%$ of new female prisoners (Ministry of Justice, Japan, 2016). In England and Wales, the number of prisoners aged fifty and over increased by $200 \%$ in the decade to 2018 and those age $40-49$ increased by around 75\% (Ministry of Justice, UK, 2018). In comparison, over the same time period, the number of prisoners in England and Wales age 21-29 decreased, while those age 30-39 remained roughly the same (Ministry of Justice, UK, 2018).

The definition of 'older', when referring to individuals in the criminal justice system, is inconsistent in the research literature. However, increasingly researchers are considering individuals as young as fifty as 'older' in criminal justice settings (e.g. Gal, 2003; Aday \& Krabill, 2013; Wilkinson \& Caulfield, 2017). Research examining the prison population notes the accelerated ageing process and high levels of cognitive decline, compared to the general population (Stevens et al., 2018; Davis, Maclagan \& Shenk, 2016) and the rise in older prisoners is problematic for a number of reasons. An increase in this group raises questions about the appropriateness and effectiveness of current prison regimes (Baidawi et al., 2011; Trotter \& Baidawi, 2015), which are typically designed to be suitable for younger adults. Wilkinson and Caulfield (2017) note that, in prisons in England and Wales, there is often a lack of meaningful activity suitable for older prisoners. This could contribute to the onset of cognitive decline, with which can come increased levels of violence (Davis, Maclagan \& Shenk, 2016). Concerns have also been raised about the prevalence of mental and physical health problems in older prisoners (Lemieux et al., 2002), and the resource implications of supporting these needs (Canada et al., 2019; O'Hara et al., 2016). 


\subsection{The characteristics and needs of older prisoners}

Some research has sought to explore the characteristics of older prisoners. Lemieux et al (2002) presented trends from US data, noting that older prisoners tended to be unmarried, white, male, employed prior to incarceration, but never graduated from high school. Older prisoners were either career criminals (prison recidivists), old offenders (first incarcerated age 55 or older), first offenders (first incarcerated before the age of 55), or 'old-timers' (growing old in prison) - these categories were first highlighted by Goetting (1984). While it has been argued that the older population in prison can be vulnerable and subject to victimisation (Baidawi, Trottter \& Flynn, 2016, Wilkinson \& Caulfield, 2017), Lemieux et al (2002) found evidence to support that older people were likely to be arrested for aggravated assault, larceny theft, sex offences, and homicide, challenging assumptions about vulnerability. Recent research supports this, with violent crimes in the older population increasing in prevalence in the UK (The Prison Reform Trust, 2018). There is evidence that older people are more likely than younger people to be arrested for alcohol and drug-related matters (Putkonen et al., 2010; Peterson, 1998; Wong, Lumsden, Fenton and Fenwick, 1995) and crimes against the person (Feldmeyer \& Steffensmeier, 2007). In England and Wales, older males in prison are more likely to be serving a sentence for offences that are sexual in nature ( $45 \%$ of all older men in prison) and/or involve violence against the person ( $23 \%$ of all older men in prison) than any other offence type (Prison Reform Trust, 2019).

As noted above, with the increase in older prisoners comes an increase in the prevalence of mental and physical health Issues. Commonly reported illnesses issues are psychiatric, cardiovascular, musculoskeletal and respiratory (Prison Reform Trust, 2008; Howse, 2011). Older offenders typically have a high prevalence of chronic health conditions (Merten, Bishop \& Williams, 2012; Fazel, et al., 2002) including 9\% with mobility issues reported by Fazel, et al. (2002). In the United Kingdom, a Department of Health survey (1999-2000) highlighted that $85 \%$ of prisoners aged 60 and over had one or more major illnesses reported in their medical records, while $83 \%$ reported at least one chronic illness or disability. Mental health issues are thought to affect half of this population with many individuals experiencing depression arising as a result of imprisonment (Merten, Bishop \& Williams, 2012). Despite these figures, mental health issues are often overlooked by those in contact with the older population (Kingston, Mesurier, Yorston, Wardle \& Heath, 2011).

Much of the literature has focused on in-prison initiatives for older prisoners, which are typically responsive rather than systematically planned and thoroughly grounded in an evidence-based understanding of the characteristics and needs of this group (Caulfield \& Wilkinson, 2017). The 
international rise in the older prison population and the challenges posed by this suggests a need to thoroughly review what the research literature to date has said about the needs and characteristics of this group. A better and more coordinated understanding of older prisoners could: a) guide the development of regimes that are less reactive and support the specific needs of older offenders, including the need for meaningful activities while in prison (Hayes, Burns, Turnbull, and Shaw, 2013; NACRO, 2009; Wilkinson \& Caulfield, 2017); b) allow for fuller consideration of the risk profile of this group; and c) provide evidence to support the development of appropriate assessment and treatment.

The aim of this paper is to systematically search the literature to select and review all existing and relevant studies that explore the needs and characteristics of older prisoners (using 50 years and over to be inclusive of the variety of definitions found in the literature), excluding their in-prison programme experiences.

\section{Research Question}

What are the characteristics and needs of older prisoners?

\subsection{Method}

\subsection{Search Strategy}

Databases (see appendix A) were searched using the search terms and strings outlined in appendix B. A total of $\mathbf{3 8 8 8}$ papers were imported into Mendeley from the database searches. The research team manually screened the titles and abstracts of the imported papers against the basic search criteria, reducing the total relevant papers to 630 . Duplicates were automatically removed by Mendeley using paper title, author(s), and year order, leaving a total of 608 papers. The research team manually searched and removed further duplicates by author, leaving 594 papers. Twelve of these were book reviews and two were tender documents, therefore they were also removed. The research team removed 146 papers due to publication date being before 2001 as - based on Public Health England statistics (Munday, 2017), US data (Gross, 2007), and reporting on global prison trends (Allen, 2015) - 2002 is when the significant rise in older offenders began. This left 433 papers.

\subsection{Selection Criteria}

The inclusion and exclusion criteria (see below) were discussed in relation to the research aim, and the research team looked through a sample of studies together as an early moderation exercise to 
check the application of inclusion and exclusion criteria before performing the exercise. Using Mendeley, two researchers applied the inclusion and exclusion criteria by marking the remaining 433, indicating the papers that focused on the general needs and characteristics of the population and removal of papers that focused on health and social care/ in prison treatment or intervention programmes. Papers that focussed solely on treatment or interventions were excluded as the current systematic review focuses on needs and characteristics rather than treatment programmes and their effectiveness. However, papers containing substantial information about prison or forensic assessments did remain (e.g. Fazel \& Grann, 2002) as these papers could contain insight information regarding the characteristics of older prisoners. The researchers assessed half of the remaining papers each and moderated each other's reviews. A sample of 20 papers, ten from each researcher, were reviewed in the early moderation process. The paper by Loeb et al. (2011) is an example of a paper that had some mention of characteristics but focussed primarily on in-prison health care management factors and therefore was excluded.

After the sifting exercise $\mathbf{5 4}$ papers remained for full text review. After full text review, and the application of the inclusion and exclusion criteria, $\mathbf{3 0}$ papers remained, but a further nine were removed upon discussion due to the focus and nature of the papers. One of these two papers was a short commentary review and the other described a new model of working in Japan. See PRISMA diagram (appendix $\mathrm{C}$ ) for more information about the removed and remaining papers.

\subsection{Inclusion and Exclusion Criteria}

Include

Literature reviews

Papers in English language

Demographic information on the older offending population $^{1}$

Characteristics and needs of the older offending population $^{2}$

Studies with assessment data

\section{Exclude}

Non-English language

Book reviews

Introductory topic overviews

Health and social care responses/treatment

Papers published before 2002

Papers capturing solely in-prison experiences

Papers presenting solely reasons for the rise

\footnotetext{
${ }^{1}$ Older offending generally, as opposed to only older prisoners. The research team identified that research on needs and characteristics has not only looked at prison groups, and so excluding studies focused on arrest data, for example, may exclude important learning

2 In this systematic review paper we use the terms needs and characteristics in a broad sense to include information on health (including mental health), historical information presented about older prisoner's lives, criminogenic needs, current offence type, offending history background. The inclusion criteria referring to needs and characteristics were purposely kept broad to reduce the risk of useful information being omitted from the search results.
} 
in this population

\subsection{Data extraction and analysis}

The remaining 21 papers were analysed and synthesised drawing on an approach similar to that proposed by Whittemore and Knafl (2005) of data reduction, data display, data comparison, and verification of conclusions. This approach was appropriate given the ethos of a review method that is inclusive of diverse study methodologies (e.g. interviews, focus group, survey data with quantitative data). This procedure allowed for the process of identifying patterns, which were then grouped together to form the overarching themes.

\subsection{Results}

Table 1.0 shows that of the 21 papers included in this review, seven were review papers, four were primary empirical studies, and 10 papers presented analysis of existing data sets. Table 1.0 presents information about types of papers and samples included (e.g. country of origin). Table 1.1 presents a summary of the key information and findings from each paper relevant to the research question: What are the characteristics and needs of older prisoners? 
[Insert Table 1.0 outline of papers included]

Table 1.1 Summary of $k f, f$ findings from the studies included in this review

\begin{tabular}{|c|c|c|}
\hline Reference & Paı ucir ants 'population size & Key findings \\
\hline $\begin{array}{l}\text { Baidawi, Turner, } \\
\text { Trotter, } \\
\text { Browning, } \\
\text { Collier, Connor } \\
\text { \& Sheehan } \\
\text { (2011) }\end{array}$ & $\begin{array}{l}\text { - } \quad \text { Review } \text { apr : / position paper } \\
\text { - } \quad \text { Older people }(50)\end{array}$ & $\begin{array}{l}\text { - Makes a case that defining the 'older prisoner' is essential in order to do comparative research and a } \\
\text { lack of clarity can impede a firm evidence base being formed around related issues, for example, } \\
\text { offence types, recidivism rates, health concerns and prison management programs. } \\
\text { - It makes a case for further complexity of minority groups within the older population (e.g. females } \\
\text { ar '.ndigenous in the AUS population). }\end{array}$ \\
\hline $\begin{array}{l}\text { Beaufrère, } \\
\text { Belmenouar \& } \\
\text { Chariot (2014) }\end{array}$ & $\begin{array}{l}\text { - Sample of } 180 \text { ( } 1 \% \text { of total arrest } \\
\text { records } 15,481) \\
\text { - Older people in police } \\
\text { custody }(60+) 92 \% \text { male and } 8 \% \\
\text { female } \\
\text { - } \text { Arrest at age } 60+\text { but no } \\
\text { distinction between career } \\
\text { criminals/old offenders }\end{array}$ & 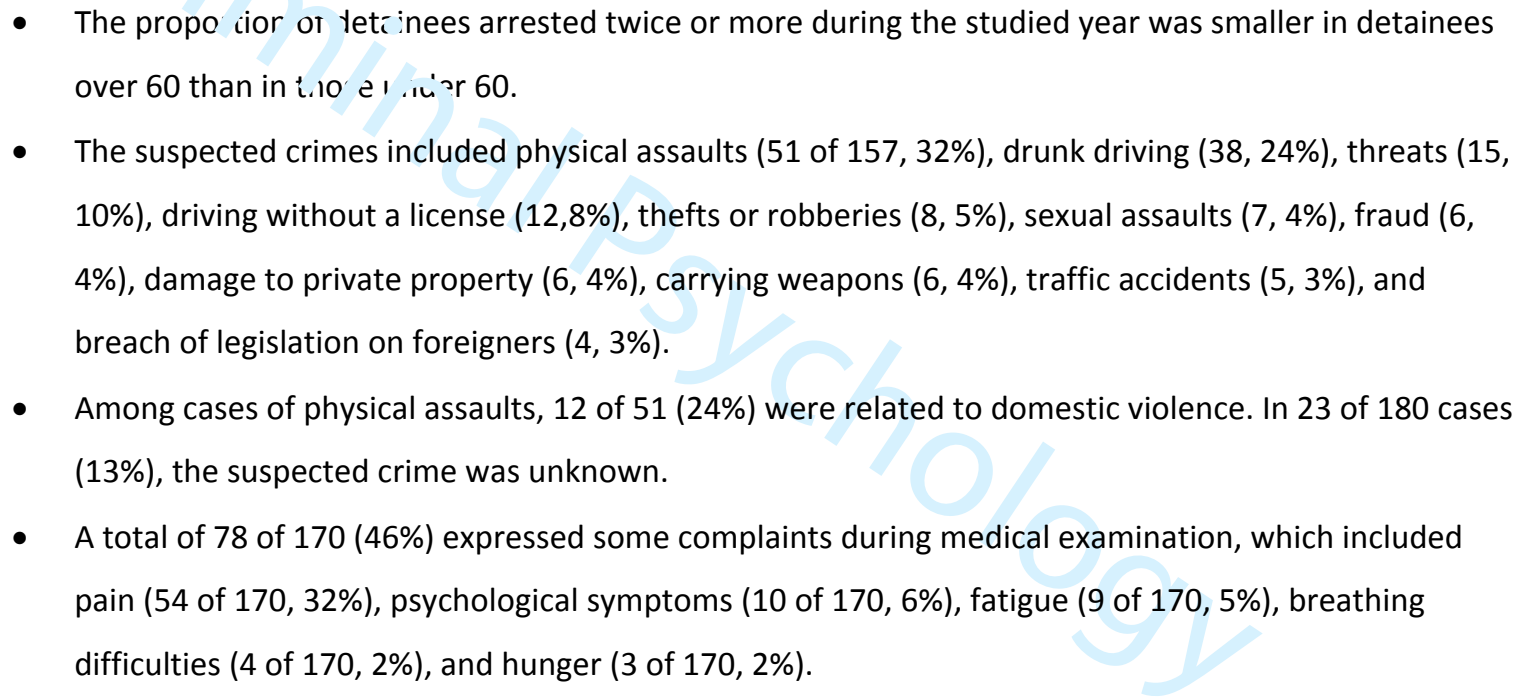 \\
\hline Block (2013) & $\begin{array}{l}\text { - Sample of } 476(1.7 \% \text { of } 27,561 \\
\text { cases). }\end{array}$ & $\begin{array}{l}\text { Reviews data from Chicago Homicide Dataset, highlighting the following trends in the data: } \\
\text { - } \quad \text { Older offenders were more likely than younger adult offenders to have killed an intimate partner. }\end{array}$ \\
\hline
\end{tabular}




\begin{tabular}{|c|c|c|}
\hline & $\begin{array}{l}\text { - Older homicide perpetrators }(60+) \\
54 \text { females and } 422 \text { males } \\
\text { - Arr'st at age } 60+\text { but no } \\
\text { distinction in analysis between } \\
\text { career criminals/old offenders }\end{array}$ & 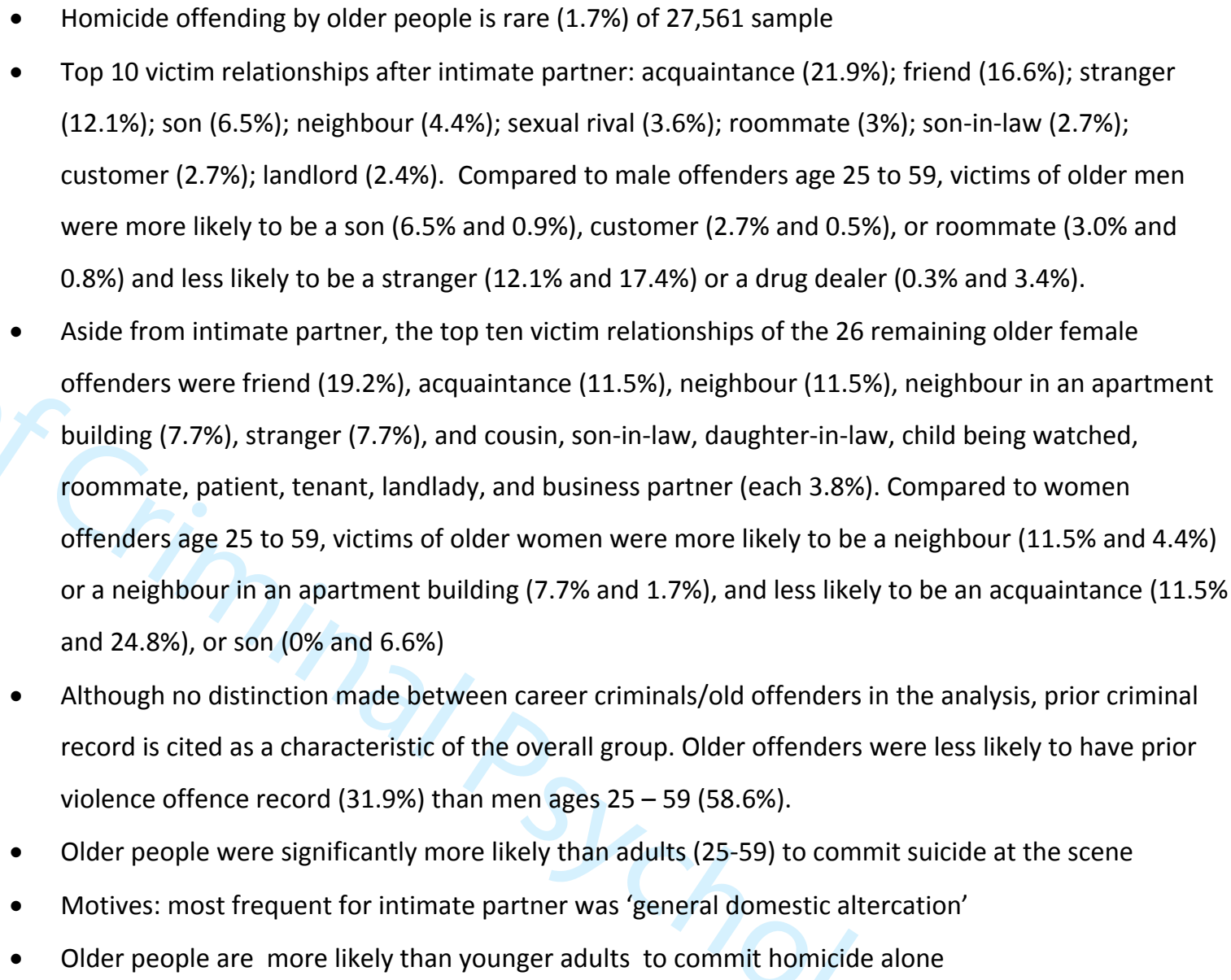 \\
\hline Booth (2016) & $\begin{array}{ll}- & \text { Review paper } \\
\text { - } & \text { Older people who have sexually } \\
\text { offended }\end{array}$ & $\begin{array}{l}\text { - This paper highlights older prisoners needs, health and psychiatric health and issues with sex offender } \\
\text { risk assessment. This paper argues that the widely used RNR model focusses on criminogenic needs } \\
\text { but does not include mental health needs relevant to an older population (e.g. cognitive decline and } \\
\text { hearing impairments). } \\
\text { - This paper makes a case for the over measurement of risk in older offenders, due to the lack of }\end{array}$ \\
\hline
\end{tabular}




\begin{tabular}{|c|c|c|}
\hline & & $\begin{array}{l}\text { acknowledgement of the relationship between age and testosterone decline, in relation to the } \\
\text { relationship between testosterone and sexual drive. } \\
\text { Notes that individuals experience issues and difficulties solving interpersonal situations; 20\% referral } \\
\text { cognitive impairment; severe mental illness, of whom } 57 \% \text { had depression, } 25 \% \text { had schizophrenia, } \\
\text { and } 18 \% \text { had bipolar illness. }\end{array}$ \\
\hline $\begin{array}{l}\text { Centre for } \\
\text { Policy on Ageing } \\
\text { (2016) }\end{array}$ & 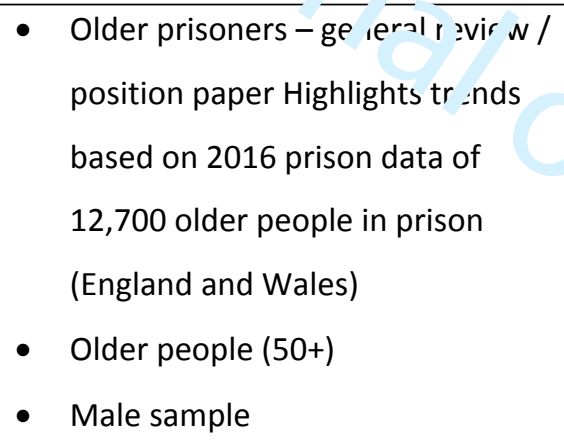 & $\begin{array}{l}\text { - Notes that sexual offences and violence against the person are higher in 50+ male offenders than } \\
\text { younger offenders. } \\
\text { Suggests that special needs of older prisoners include: social exclusion /segregation; medication; } \\
\text { elease planning and end of life care provision. }\end{array}$ \\
\hline $\begin{array}{l}\text { Chua, Cheung, } \\
\text { Friedman \& } \\
\text { Taylor (2018) }\end{array}$ & $\begin{array}{l}\text { - Systematic review } \\
\text { - } \text { Older people (65+) } \\
\text { - First time older individuals who } \\
\text { have committed sex } \\
\text { offences(recent \& historic) } \\
\text { - The review includes } 7 \text { papers (5 } \\
\text { case report papers \& } 2 \\
\text { retrospective research studies) } \\
\text { with a total sample of } 26 \\
\text { individuals }\end{array}$ & $\begin{array}{l}\text { The studies included in this r }\lrcorner v \text { ar }\lrcorner \text { ar were summarised to highlight the characteristics of first-time } \\
\text { older sex offenders, noting that: } \\
\text { - First time older sex offender's victims are often vulnerable (either minors or with intellectual } \\
\text { disability). } \\
\text { - Lack of either screening or reporting with regards to psychological and cognitive assessments of older } \\
\text { offenders. In the few studies where cognitive assessments had taken place they were not elaborated } \\
\text { on. } \\
\text { - Physical disorder such as physical disability, chronic respiratory failure, difficulties in verbal } \\
\text { communication, ambulation (used a wheelchair), and urinary incontinence were, similarly, reported in } \\
\text { few studies. }\end{array}$ \\
\hline
\end{tabular}




\begin{tabular}{|c|c|c|}
\hline & & $\begin{array}{l}\text { dementia, Alzheimer's disease, frontal lobe dysfunction and chronic schizophrenia. } \\
\text { - The review discussed two types of older offenders (1) repeat offenders but not detected until later life } \\
\text { (2) late offenders with a higher proportion of neurocognitive disorder. } \\
\text { - The review highlights a lack of consistent recording and reporting of characteristics and demographics } \\
\text { and a need for better designed studies. }\end{array}$ \\
\hline $\begin{array}{l}\text { Curtice, Parker, } \\
\text { Wismayer \& } \\
\text { Tomison (2003) }\end{array}$ & $\begin{array}{l}\text { - } \text { Based on 11-year survey of } \\
\text { referrals to regional forensic } \\
\text { - } \text { psychiatric services } \\
\text { - } \quad \text { Older people (65+) } 32 \text { case reviews } \\
\text { - } 31 \text { males and } 1 \text { female } \\
\text { - } 19 \text { were first time offenders }\end{array}$ & $\begin{array}{l}\text { - Sexual offending was the most common index offence (56\%); violent offences ( } 25 \%) \text {; } \\
\text { murder/manslaughter ( } 9 \% \text { ) and attempted arson ( } 3 \%) \text { of cases. } \\
\text { - Although no distinction made between career criminals/old offenders in the analysis, prior criminal } \\
\text { record is cited as a characteristic of the overall group. The majority ( } 59 \%) \text { were first time offenders } \\
\text { with no previous history. } \\
\text { - There was no diagnosis of mental disorder in } 56 \% \text { of cases, however, where there was a diagnosis, } \\
\text { dementia was the most common ( } 19 \%) \text {; depression (6\%); schizophrenia (6\%) mild learning disability } \\
(3 \%) \text {. This paper found poor use of diagnostic tools and investigations in the assessment process. } \\
\text { Alcohol history was noted in } 79 \% \text { of cases, } 41 \% \text { of patients being regular users. } \\
\text { - This paper suggests that an integrated approach to assessment and management of older forensic } \\
\text { populations is required. }\end{array}$ \\
\hline $\begin{array}{l}\text { Fazel \& Grann } \\
\text { (2002) }\end{array}$ & $\begin{array}{l}\text { - Sample of } 210 \\
\text { Older people }(60+) \\
\text { - } 16 \text { females and } 194 \text { males } \\
\text { - } \quad \text { Forensic psychiatric evaluations } \\
\text { - No distinction between career } \\
\text { criminals/old offenders }\end{array}$ & $\begin{array}{l}\text { - There appear to be important differences in psychiatric morbidity between older offenders and } \\
\text { younger offenders who come into contact with forensic psychiatric services. } \\
\text { Established that } 7 \% \text { had a diagnosis of dementia; } 32 \% \text { psychotic illness; } 8 \% \text { depressive or anxiety } \\
\text { disorder; } 15 \% \text { substance abuse or dependence; } 20 \% \text { personality disorder. Older offenders were } \\
\text { significantly less likely than younger offenders to be diagnosed with schizophrenia or personality } \\
\text { disorder and more likely dementia or affective psychosis. }\end{array}$ \\
\hline $\begin{array}{l}\text { Fazel, Hope, } \\
\text { O’Donnell \& }\end{array}$ & $\begin{array}{l}\text { - Sample of } 203 \text { (101 individuals } \\
\text { who committed sex offences and }\end{array}$ & $\begin{array}{l}\text { - Found } 6 \% \text { of older individuals who committed sex offenses had a psychotic illness; } 7 \% \text { major } \\
\text { depressive episode; } 33 \% \text { personality disorder; } 1 \% \text { dementia. These figures did not significantly differ }\end{array}$ \\
\hline
\end{tabular}




\begin{tabular}{|c|c|c|}
\hline Jacoby (2002) & 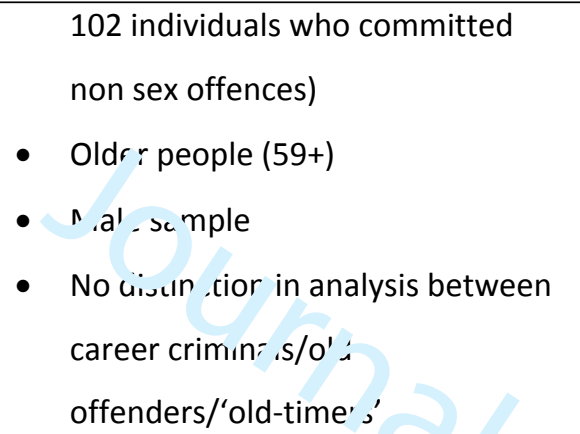 & $\begin{array}{l}\text { from older non-sex offenders. } \\
\text { Differences occurred when considering personality traits - sex offenders had more schizoid, } \\
\text { obsessive-compulsive and avoidant traits, and fewer antisocial traits compared with non-sex } \\
\text { offenders. } \\
\text { - Although no distinction was made between career criminals/old offenders/'old-timers' in the analysis, } \\
\text { median time spent in prison was reviewed and not significantly different for those who had } \\
\text { committed sex offences compared with those who had not committed sex offences. }\end{array}$ \\
\hline $\begin{array}{l}\text { Fazel, } \\
\text { O'Donnell, } \\
\text { Hope, Gulati \& } \\
\text { Jacoby (2007) }\end{array}$ & $\begin{array}{l}\text { - Sample of } 100 \text { prisoners } \\
\text { - Older people (59+) } \\
\text { - Male sample } \\
\text { - Sex and non-sex offence } \\
\text { comparison } \\
\text { - No distinction in analysis between } \\
\text { career criminals/old } \\
\text { offenders/'old-timers' }\end{array}$ & $\begin{array}{l}\text { This paper found no evidence to support that older sex offender's frontal lobes differ from older non- } \\
\text { ex offender's frontal lobes. There were no significant differences in test scores for frontal lobe tasks } \\
\text { between the two prisoner samples. } \\
\text { - There were no significant differences in socio-economic class, although there was a trend for sex } \\
\text { offenders to be from lower socio-economic classes. . } \\
\text { - } \text { Although no distinction made between career criminals/old offenders/'old-timers' in the analysis, } \\
\text { committed sex offences compared with those who did not commit sex offences. }\end{array}$ \\
\hline $\begin{array}{l}\text { Feldmeyer \& } \\
\text { Steffensmeier } \\
(2007)\end{array}$ & $\begin{array}{l}\text { - } \text { Older people }(55+) \\
\text { data - reports from uniformed } \\
\text { police officers } \\
\text { - } \quad \text { Data was taken across different } \\
\text { years for comparison (e.g. } 1980= \\
833 \text { arrests; } 1990=657 \text { arrests and } \\
2004=590 \text { arrests in } 55+\text { ) }\end{array}$ & $\begin{array}{l}\text { Looked at trends in older offender crime rates over } 25 \text { years noting that there has been very little } \\
\text { change in the profile of the older offender, with arrests continuing to be overwhelmingly for minor } \\
\text { offences and alcohol-related violations. } \\
\text { - Shifts in crime committed by older people have been paralleled by similar trends among the } \\
\text { nonelderly, indicating that recent social, economic, and legal changes have had similar impacts on } \\
\text { arrest patterns across age groups. }\end{array}$ \\
\hline
\end{tabular}




\begin{tabular}{|c|c|c|}
\hline & $\begin{array}{l}\text { No distinction in analysis between } \\
\text { career criminals/old offenders }\end{array}$ & \\
\hline $\begin{array}{l}\text { Greene \& } \\
\text { Gibson (2013) }\end{array}$ & $\begin{array}{l}\text { - } \quad \text { Boc': chapter - review } \\
\text { - } \quad \text { id . r } \mathrm{N} \text { ople in the legal system }\end{array}$ & $\begin{array}{l}\text { - Reports that older prisoners are far less likely to recidivate compared to the younger population. } \\
\text { - Some key features for older individuals in prison are the accelerating aging process; low levels of self- } \\
\text { care; high psychiatric conditions, social and emotional affects; victimisation; cut off contact to reduce } \\
\text { their suffering and negative self-reflection of their lives. } \\
\text { - Notes that older offenders present issues as diverse as: health care needs; end-of-life care and } \\
\text { decisions; social security, medication, and Medicare entitlements; estate planning, wills, trusts, and } \\
\text { probate, cognitive impairment and guardianship, and elder abuse. }\end{array}$ \\
\hline Gross (2007) & $\begin{array}{ll}\text { - } & \text { Book chapter - review } \\
\text { - } & \text { Older people (55+) in the legal } \\
& \text { system }\end{array}$ & $\begin{array}{l}\text { Provides a summary of information older offenders in the USA from 1971-2004. During the period } \\
\text { - The } 55-64 \text { age group showed an increase in the number of violent, property, and drug crime arrests } \\
\text { during } 2000-2004 \text {. } \\
\text { - Violent crime rate decreased slightly for those aged } 65+\text {, while property and drug crime rates } \\
\text { remained relatively stable for this age group. }\end{array}$ \\
\hline $\begin{array}{l}\text { Hunt et al. } \\
\text { (2010) }\end{array}$ & $\begin{array}{l}\text { - } \text { Sample of } 365 \\
\text { Older homicide perpetrators ( } 311 \\
\text { - } \quad 90 \% \text { were } 45-64 \text { and } 54 \text { were } 65+\text { ) } \\
\text { female and } 10 \% \text { were } \\
\text { - } 8 \text {-year period (1997-2004) } \\
\text { - Data from the National } \\
\text { Confidential Inquiry into Homicide } \\
\text { by people with Mental Illness }\end{array}$ & $\begin{array}{l}\text { Highlights some key factors and characteristics of older perpetrators of homicide, such as: } \\
\text { - Perpetrators aged } 65 \text { and over were most likely to use strangulation/suffocation and the victim was } \\
\text { more often a female and a family member or spouse. } \\
\text { - Older perpetrators had high rates of affective disorder and were more likely to be mentally ill at the } \\
\text { time of the offence. } \\
\text { - Of the } 54 \text { older perpetrators who killed a family member or spouse, seven (13\%) were considered } \\
\text { 'mercy killings'. } \\
\text { - Although no distinction made between career criminals/old offenders in the overall analysis, } 6 / 54 \text { of } \\
\text { the } 65+\text { group and } 92 / 311 \text { of the } 45-64 \text { group had a previous conviction for a violent offence. }\end{array}$ \\
\hline
\end{tabular}




\begin{tabular}{|c|c|c|}
\hline & $\begin{array}{l}\text { (Appleby et al., 1999) } \\
\text { - No distinction in analysis between } \\
\text { car' er criminals/old offenders }\end{array}$ & \\
\hline $\begin{array}{l}\text { Overshott et al. } \\
\text { (2012) }\end{array}$ & 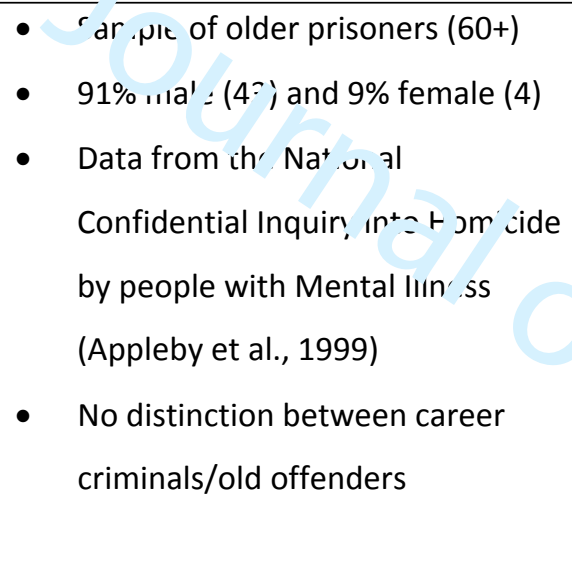 & $\begin{array}{l}\text { - } 2662 \text { perpetrators convicted of homicide were reported to the Inquiry. } 47 \text { (2\%) of the perpetrators } \\
\text { were aged } 60 \text { years or older; } 22 \text { of the } 47 \text { were } 65 \text { years or older. } \\
\text { - Homicide incidents perpetrated by older people typically involved a man killing his partner in an } \\
\text { impulsive manner. The most common method was by using a sharp instrument ( } 34 \%) \text {, followed by the } \\
\text { use of a blunt instrument ( } 26 \%) \text {. The use of firearms was rare ( } 11 \%) \text {. } \\
\text { - Perpetrators aged } 65 \text { years and older were significantly more likely to kill a current or former } \\
\text { spouse/partner and less likely to kill an acquaintance. } \\
\text { - Forty-four per cent of perpetrators over } 65 \text { years old suffered from depression at the time of the } \\
\text { offence. Rates of schizophrenia and alcohol dependence were low. }\end{array}$ \\
\hline $\begin{array}{l}\text { Putkonen, } \\
\text { Weizmann- } \\
\text { Henelius, Repo- } \\
\text { Tiihonen, } \\
\text { Lindberg, } \\
\text { Saarela, Eronen } \\
\text { \& Häkkänen- } \\
\text { Nyholm (2010) }\end{array}$ & $\begin{array}{l}\text { - } \quad \text { Sample of } 25 \\
\text { - } \quad \text { Older homicide perpetrators (60+) } \\
\text { - } \quad \text { Three females and } 22 \text { males } \\
\text { - } \quad \text { Analysis of large national dataset } \\
\text { - } \quad \text { Explores differences between } \\
\text { career criminals/old offenders }\end{array}$ & $\begin{array}{l}\text { Presents data on older homicide perpetrators who were in a forensic psychiatric examination in Finland } \\
\text { 1995-2004 and their gender-matched comparison group of younger homicide offenders. The study found } \\
\text { that: } \\
\text { - Offenders } 60 \text { years or older were diagnosed less often than the younger ones with drug dependence } \\
\text { and personality disorders and more often with dementia and physical illnesses. } \\
\text { - The mean Psychopathy Checklist-Revised total scores as well as factor and facet scores were lower in } \\
\text { the } 60 \text { or older age group. The } 60 \text { or older age group had significantly lower scores than younger } \\
\text { perpetrators on eight individual items of social deviance. The interpersonal / affective factor } 1 \text { scores } \\
\text { did not differ. } \\
\text { - The older offenders with previous criminal offending differed from those without in two ways: they } \\
\text { had higher rates or alcohol abuse / dependence ( } 75 \% \text { vs. 31\%) and were diagnosed more often with a } \\
\text { personality disorder ( } 67 \% \text { vs. } 23 \%) \text {. }\end{array}$ \\
\hline
\end{tabular}




\begin{tabular}{|c|c|c|}
\hline $\begin{array}{l}\text { Reutens, } \\
\text { Nielssen \& } \\
\text { Large (2015) }\end{array}$ & 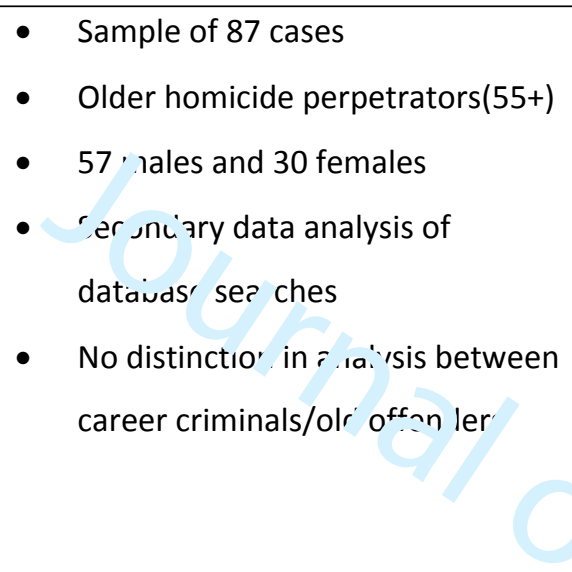 & $\begin{array}{l}\text { Presents a systematic search of legal, criminological and media databases for cases of homicide committed } \\
\text { by people aged } 55 \text { and over, during the } 18 \text { years from } 1993 \text { to } 2010 \text {. Eighty-seven cases were identified } \\
\text { through databases. Legal documents were obtained for } 70 \text { offenders (about } 5 \% \text { of homicides committed in } \\
\text { NSW in the period of the study). } \\
\text { - The proportions of male offenders and rates of firearm use were similar to other age groups. Twelve } \\
\text { of the } 14 \text { homicides using guns occurred outside the metropolitan area. } \\
\text { - Older offenders were more likely than younger perpetrators to have cognitive impairment or } \\
\text { psychotic illness. }\end{array}$ \\
\hline $\begin{array}{l}\text { Rodriguez, } \\
\text { Boyce \& Hodges } \\
\text { (2017) }\end{array}$ & $\begin{array}{l}\text { - Sample of } 100 \text { ( } 32 \text { first time sex } \\
\text { offenders; } 36 \text { historic sex } \\
\text { offenders; } 32 \text { non sexual } \\
\text { offenders) } \\
\text { - Older people (50+) } \\
\text { - Male sample } \\
\text { - Empirical study }\end{array}$ & $\begin{array}{l}\text { Presents the findings from a battery of neuropsychological measures administered to } 100 \text { participants ( } 32 \\
\text { first time sex offenders; } 36 \text { historic sex offenders; } 32 \text { non sexual offenders). } \\
\text { - Both FTSOs and HSOs showed significant impairment on tests of executive function (including verbal } \\
\text { fluency, trail-making, and the Hayling test of response inhibition) as well as on tests of verbal and } \\
\text { verbal memory compared to NSOs; } \\
\text { - There was no difference between the two sex offender groups. }\end{array}$ \\
\hline $\begin{array}{l}\text { Stanback \& } \\
\text { King-Kallimanis } \\
(2011)\end{array}$ & $\begin{array}{l}\text { - Sample of } 972 \\
\text { - } \text { Older homicide perpetrators (50+) } \\
\text { - Male sample } \\
\text { - Secondary data analysis of } \\
\text { - } \quad \text { No distinction in analysis between } \\
\text { career criminals/old offenders }\end{array}$ & $\begin{array}{l}\text { Presents analysis of the Chicago Homicide Dataset (1965-1995) and investigates covariates associated with } \\
\text { four categories of homicide committed by older offenders: intimate, family, acquaintance, and unrelated } \\
\text { victims. The findings reveal that: } \\
\text { - in intimate and family comparisons, women were at a significantly higher risk of victimisation. } \\
\text { - Crimes that occurred in residences were significantly associated with all three homicides groups } \\
\text { - Thempared with unrelated homicides. } \\
\text { - The of alcohol was significant in crimes where an acquaintance was the victim. }\end{array}$ \\
\hline
\end{tabular}




\begin{tabular}{|c|c|c|}
\hline $\begin{array}{l}\text { Williams \& } \\
\text { Rikard (2005) }\end{array}$ & 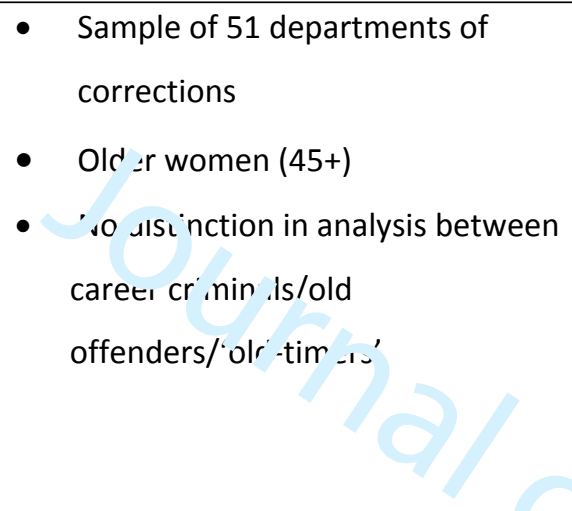 & $\begin{array}{l}\text { Explores policies and programs for older female prisoners. Interviews were conducted with the Federal } \\
\text { Bureau of Prisons and state Department of Corrections ( } N=40 / 51) \text { about their policies and programs for } \\
\text { older female prisoners. } \\
\text { - While } 23 \text { States provided care for ageing male prisoners, only two reported providing provision for } \\
\text { older female prisoners. } \\
\text { - The discussion highlights that female prisoners tend to have greater mental health needs and it is } \\
\text { important to highlight the gendered needs of older prisoners. } \\
\text { - As this paper focuses on programs and policies it is now outdated. }\end{array}$ \\
\hline Yorston (2010) & $\begin{array}{ll}\text { - } & \text { Older prisoners } \\
\text { - } & \text { Review paper }\end{array}$ & $\begin{array}{l}\text { Primarily focuses on the characteristics of older prisoners. The paper highlights that: } \\
\text { - the types of offences being committed has remained stable } \\
\text { - there is an over-representation of sexual offences against children } \\
\text { - there are higher levels of psychotic and mental disorders in older homicide offenders } \\
\text { - there is a lack of evidence around some types of crime (e.g. arson and acquisitive offending) } \\
\text { - Alcohol is becoming recognised as a problem. } \\
\text { - The paper also mentions that there is a lack of research about delirium and personality disorders, } \\
\text { - } \quad \text { some research about dementia. } \\
\text { the review suggests older people may make greater use of firearms (findings from US studies) and } \\
\text { there lower arrest and conviction rates for older people. }\end{array}$ \\
\hline
\end{tabular}




\subsection{Summary of results and concluding discussion}

The population focus of the papers was as follows: General older prisoners, seven papers; Female older prisoners, one paper; Psychiatric evaluated older prisoners, two papers; Older sex offenders, five papers; Older homicide offenders, six papers (see table 1.0 for the breakdown). Thematic summaries of these papers are presented below, under these headings.

\subsection{General}

Four of the seven papers considered within this category were review papers. The papers that presented new research findings included data outlining the types of offences committed by this group. Beaufrère et al. (2014) found physical assaults were the main suspected crime in their sample of 180 older suspects in France. The Centre for Policy on Ageing (2016) noted that violent crimes remained consistent across all age groups for male offenders in the UK (under $25 ; 25-49 ; 50-59 ; 60+$ ) while the proportion of sexual offences were highest in older offenders (13\% of $25-49$ year olds; $34 \%$ of 50-59 year olds; $\& 59 \%$ of $60+$ ). The types of offence committed by female offenders remained relatively stable across age groups (Centre for Policy on Ageing, 2016). Some studies note the relatively stable nature of offending by older people. Feldmeyer and Steffensmeier (2007) for example found very little change in the profile of the older offender, with arrests mainly for minor offences and alcohol-related violations. However, the most recent data in that study is now 15 years old. Similarly, Yorston's (2010) review paper suggests that the types of offences being committed by older people have remained stable. However, contradictions appear in the literature. Gross' (2007) review paper, for example, notes an increase in violent crime among older people. While contradictions appear, both Feldmeyer and Steffensmeier (2007) and Yorston (2010) highlighted the increased recognition of the role of alcohol in offences committed by older people and Yorston (2010) notes the overrepresentation of sexual offences committed by older offenders.

A number of papers included in this review discuss the health needs of this population, including physical health issues as well as psychiatric and psychological health concerns (Beaufrère et al., 2014; Centre for Policy on Ageing, 2016; Greene \& Gibson, 2013; Yorston, 2010). The prison environment is designed for young and able-bodied people (Baidawi et al., 2011) and older adults are often not willing or able to participate in correctional, criminal, or probation programmes (Greene and Gibson, 2013). The rise in numbers of older prisoners makes it difficult to ignore the needs of this population. The potential vulnerability and victimisation of older prisoners is also noted in some studies (Centre for Policy on Ageing, 2016; Baidawi et al., 2011). Yorston (2010), however, 
highlights that - when considering risk assessment - the 'potential for causing harm should never be underestimated on the basis of age alone' ( $p$ 695).

The research in this section presents agreement over the existence of physical and mental health needs in the older offender population, but there is a lack of consistency in terms of the reported offending patterns of this group. The various methodologies employed (e.g. some present a snapshot in time, other comparisons over time, others comparisons against other age groups) make comparison between studies difficult. Baidawi et al makes the case that defining the 'older prisoner' is essential in order to do comparative research and a lack of clarity can impede a firm evidence base being formed around related issues, for example, offence types, recidivism rates, health concerns and prison management programs. The data presented in these empirical and review studies is sometimes based on small sample sizes (e.g. Beaufrère et al., 2014), varied in methodology, and typically fails to make a clear distinction between career criminals/old offenders.

\subsection{Female}

Williams and Rikard (2005) conducted the only study found through this systematic review to focus solely on older female prisoners. While their research focused on policies and programs, Williams and Rickard (2005) highlight that the characteristics of older female prisoners may mean they are particularly low risk, but that there is a need to take account of gender-specific needs. For example, women in contact with the criminal justice system have particularly high levels of need around mental health (Caulfield, 2016). Baidawi et al. (2014), in their review paper, note the likely complexity of 'minority' groups, including women.

Eight papers (Beaufrère et al., 2014); Block, 2013; Curtice et al., 2003; Fazel \& Grann, 2002; Hunt et al., 2010; Overshott et al., 2012; Putkonen et al., 2010; Reutens et al., 2015) include women and men in their samples, although only Block and Fazel and Grann include any breakdown of findings according to gender. Block, in her homicide study, found that older women and men were most likely to have killed an intimate partner, with friend second and acquaintance third for women (\& reversed for men). Fazel and Grann report that older women were less likely than men to be 'deemed insane' (p.911), contrary to those younger than 60. They make no further reference to gender in their analysis. Unsurprisingly, given that men make up the majority of those in contact with the criminal justice system, the numbers of women in these studies is small (ranging from 1 woman, Curtice et al. to 54 women, Block). 


\subsection{Psychiatric}

Curtice et al. (2003) found that of the 32 cases of older offenders referred to a regional psychology service in the UK, sexual offending was the most common offence. Dementia was a common diagnosis in the cases reviewed (19\%). In a review of the psychiatric evaluations of 210 older offenders, Fazel and Grann (2002, also UK) found that this group were less likely to be diagnosed with a mental health condition (including schizophrenia and personality disorders) than younger offenders, but more likely than then general offending population to be diagnosed with dementia or affective psychosis. Yorston et al., (2010) notes homicide followed by suicide is more common in older adults than younger homicide perpetrators. These findings suggest important differences in the psychiatric and cognitive needs of older and younger prisoners, which should be investigated further - and if more widely applicable - taken into account when planning provision for older prisoners. However, the limited recent published literature available on the needs of this group means more systematic research is needed in this area.

\subsection{Sex Offenders}

In his review of research on older sex offenders, Booth (2016:5) states that 'when faced with an older sexual offender, the index of suspicion for cognitive issues should be high', although he notes that the general risk level presented by this group may be lower than younger sex offenders. Fazel et al. (2002) report similarly high levels of mental health problems and neurocognitive disorders among older sex offenders and older non-sex offenders. However, they do note differences in personality traits, with older sex offenders having higher rates of schizoid, obsessive-compulsive, and avoidant traits, and fewer antisocial traits. As part of the same wider study, Fazel et al. (2007) administered frontal lobe tests to older sex offenders and older non-sex offenders, finding no significant frontal lobe differences between the two groups. The only notable difference between the groups was the average lower socio-economic status of the sex offender group. The latter sample is likely to be subset of the former (although this is not explicitly stated in the paper).

Chua et al.'s (2018) systematic review of older first time sex offenders reports a range of sexual offence types, some historic and some current/on-going, and a higher incidence of neurocognitive disorders than found in younger offenders. They report a high incidence of victims with mental illness and/or developmental disorders, with most victims being children or older people. However, despite being a systematic review paper, the overall sample considered in the paper is very small (26 individuals). Rodriquez et al.s (2017) sample of first time and historic older sex offenders demonstrated poorer neuropsychological performance than older non-sex offenders did, although 
there was no difference between the older first-time and historical offenders. Cognitive deficits may increase the risk of sexual offending due to impaired capacity in self-regulation, planning, judgment, and inhibition. The authors suggest that proportion of elderly adult sex offenders may be harbouring acquired frontal lobe pathology. However, the sample size of 100 in this study limits generalisability. Fazel et al (2007) suggest that other possible risk factors for sexual offending, such as psychosocial and criminal history, might be areas for future research.

\subsection{Homicide}

Block (2013) looked at homicide cases, finding that older offenders were more likely than younger offenders to have killed an intimate partner. Reutens et al. (2015) also found that the victims of older homicide perpetrators were likely to be female and in a domestic relationship with the offender. Older offenders in Block's sample were less likely than younger offenders to have a history of violence, more likely to commit the homicide alone, and the most frequent motive was noted as 'general domestic altercation'. Stanback and King-Kallimanis (2011)'s work suggests a need to better understand spousal relationships, which might be one important way to identify households at risk of violence (for example, stresses of late life, caregiver responsibilities). Research by Hunt et al. (2010) and Overshot et al. (2012) add support to this, finding that homicide victims of older perpetrators are likely to be a female family member or spouse. Both studies also found high rates of perpetrator mental illness at the time of the offence, particularly depression. In Reutens et al.'s study older offenders were more likely than younger perpetrators to have cognitive impairment or psychotic illness.

Hunt at al. (2010) suggest there is a need for improved recognition and treatment of mental illness in older people, and posit that preventing homicide among older people might be best achieved through more specialised GP training to improve recognition and treatment of depression. The existing research, however, underlines the complexities with Overshot et al. (2012) finding lower rates of schizophrenia and alcohol dependence than seen in younger homicide perpetrators. Putkonen et al. (2010) reporting lower levels of drug dependence and personality disorders, and lower scores of the Psychopathy Checklist, than younger perpetrators (data on older homicide perpetrators in forensic psychiatric examination). However, Putkonen et al. found higher rates of dementia and physical illness.

\subsection{Summary}


The aim of this paper was to systematically search the literature to select and review all existing and relevant studies that have explored the needs and characteristics of older prisoners. After a thorough search and selection process 21 papers, from 2002 onwards, were included in the final analysis. These papers came from the United Kingdom, Australia, France, the USA, Canada, New Zealand, Sweden, Japan, and Finland.

The contradictions within the existing evidence base make it difficult to reach firm conclusions about the needs and characteristics of older offenders. For example, some papers present older offending patterns as relatively stable over time while others suggest there have been increases in certain types of crime committed by older people (e.g. violent crime). There is, however, some consensus regarding older people who have committed certain types of offences. For example, where older people commit homicide the victim is likely to be an intimate partner.

What is clearer from the existing research are the relatively high levels of need in this group. However, inconsistencies in the existing research again underline the complexities of reaching firm conclusions, with some agreement about higher incidences of cognitive impairment - particularly in certain sub-groups of older offenders - but differences where mental health is concerned. Where research does exist on needs and characteristics, this primarily relates to older men and very little is known about older women in contact with the criminal justice system. Given the gendered nature of needs of younger adults in the criminal justice system (Caulfield, 2010) and that there are physical differences in the way men and women age (menopause, for example, is briefly discussed in Public Health England guidance on gender specific guidance for improving health and wellbeing in prisons in England: PHE, Peden et al., 2018), this is an important area for future consideration. How offending patterns and needs relate to risk and risk assessment is a point without any clear consensus.

Any conclusions drawn from the existing literature should be taken with caution. There are a relatively small number of recent papers focused on the needs and characteristics of older people in contact with the criminal justice system, and sample sizes are generally small (overall, and even smaller when broken down into sub-categories of older offenders). Furthermore, when reviewing existing studies if it not possible to compare like for like. There are various methodologies employed with some studies presenting a snapshot in time, others making comparisons over time, and others making comparisons against other age groups, making comparison between studies difficult. In this current systematic review we included older people in contact with the criminal justice system 
broadly to avoid missing important learning, but this is a further example of an inability to compare like for like. The existing research also often fails to make clear distinctions between groups of older prisoners, such as whether individuals are career criminals (prison recidivists), old offenders (first incarcerated age 55 or older), first offenders (first incarcerated before the age of 55), or 'old-timers' (growing old in prison) (Goetting, 1984). For example, Block (2013) identifies prior criminal history as one potential characteristic of those perpetrating crime at age $60+$, but does not break down her analysis to look at the separate characteristics of old offenders vs. recidivists.

Overall, there is a lack of consistent recording and reporting of characteristics and demographics and - as Chua et al. (2018) note in their review of the characteristics of first time older sexual offenders a need for better designed, more systematic studies. Perhaps even more basic a start-point, Baidawi et al (2011) make the case that defining the 'older prisoner' consistently is essential in order to do comparative research.

\subsection{Conclusion}

The prison population is ageing, and this is an international issue, yet there remains a lack of consistency about how older prisoners are defined and understood. The papers reviewed here suggest that older prisoners have significant needs, but evidence about the prevalence of needs and their relationship to factors such as offence type is mixed. Much of this is because the approach to the existing research has not been consistent.

A better understanding of patterns and precipitators would enable an evidence-based conversation about prevention. If we acknowledge, for example, that the prison environment - or certainly most current, typical prison environments - is likely to increase the speed of cognitive decline, and this may be an issue with some sub-groups of older prisoners, there are important questions here about both need and risk. Many studies also consider prisoners who have grown old in prison alongside those who have entered prison at a late age (for current or historic offences). It would be useful to look at the different factors relevant to these groups. The literature to date has also been almost exclusively focused on the older male prison population, while older women have been almost entirely excluded from the literature.

What is clear from this systematic review is that there is a lack of clear understanding about the characteristics of older prisoners as a whole, despite this being an international issue. A wealth of information exists in our criminal justice, correctional, and government systems about prisoners, 
their characteristics, their need and risk, their history, and the judicial decisions surrounding their cases. Future research should make use of these data sources to provide a much clearer understanding of this group, their routes to prison, their needs, and the challenges they present. $A$ better and coordinated understanding of the reasons behind the significant increase in the older population in prison could: a) guide the development of regimes that are less reactive and support the specific needs of older offenders, including the need for meaningful activities while in prison (Hayes, Burns, Turnbull, and Shaw, 2013; NACRO, 2009; Wilkinson \& Caulfield, 2017); b) allow for fuller consideration of the risk profile of this group; and c) provide evidence to support the development of appropriate assessment and treatment. Increased understanding of this group and the precipitating factors surrounding their offence may not only provide lessons for better supporting those convicted and reducing their needs and risk, but also may provide lessons for the prevention of such crimes. 


\section{References}

Aday, R. H., \& Krabill, J. J. (2013). Older and geriatric offenders: Critical issues for the 21st century. In L. Gideon (ed.), Special needs offenders in correctional institutions (pp. 203-232). Thousand Oaks, CA: Sage Publications.

Allen, R. (2015). Global prison trends 2015. Penal Reform International https://cdn.penalreform.org/wp-content/uploads/2015/04/PRI-Prisons-global-trends-report-LR.pdf Baidawi, S., Trotter, C., \& Flynn, C. (2016). Prison experiences and psychological distress among older inmates. Journal of gerontological social work, 59(3), 252-270.

Baidawi, S., Turner, S., Trotter, C., Browning, C., Collier, P., O'Connor, D., \& Sheehan, R. (2011). Older prisoners-A challenge for Australian corrections. Trends and issues in crime and criminal justice, (426), 1. https://www.scopus.com/inward/record.uri?eid=2-

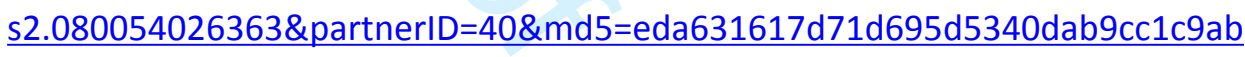
Beaufrère, A., Belmenouar, O., \& Chariot, P. (2014). Elderly arrestees in police custody cells: implementation of detention and medical decision on fitness to be detained, Forensic Science International, 241, 15-19. Retrieved from https://search.proquest.com/docview/1545300280?accountid=14685 Block, C. R. (2013). Homicide Against or by the Elderly in Chicago 1965-2000. Homicide Studies, 17(2), 154-183. https://doi.org/10.1177/1088767913478596

Booth, B. D. (2016). Elderly Sexual Offenders. Current Psychiatry Reports, 18(4), 1-7. https://doi.org/10.1007/s11920-016-0678-1

Bureau of Corrections and Philippine Statistics Authority (2015). 2015 Philippines statistics yearbook. Quezon City: Philippine Statistics Authority.

Bureau of Justice Statistics. Prisoners Series: 1990-2010. Washington, DC: Department of Justice, Office of Justice Programs, Bureau of Justice Statistics. Available at http://bjs.ojp.usdoj.gov/index.cfm?ty=pbse\&sid=40 Accessed June 2016. Canada, K. E., Barrenger, S. L., Robinson, E. L., Washington, K. T., \& Mills, T. (2019). A systematic review of interventions for older adults living in jails and prisons. Aging \& mental health, 1-9. Caulfield, L.S. (2016). Counterintuitive findings from a qualitative study of mental health in English women's prisons. International Journal of Prisoner Health, 12 (4), 216-229.

Centre for Policy on Ageing (2016). Diversity in older age: older offenders. London: Centre for Policy on Ageing. Retrieved from http://www.ageuk.org.uk/Documents/EN-GB/Forprofessionals/Policy/equality-andrights/CPA rapid review Diversity in older age Older Offenders.pdf?epslanguage=enGB?dtrk=true 
Chua, J., Cheung, G., Friedman, S. H., \& Taylor, S. (2018). What are the characteristics of first time older sexual offenders? International Psychogeriatrics, 30(5), 647-662.

https://doi.org/10.1017/\$1041610217002186

Curtice, M., Parker, J., Wismayer, F. S., \& Tomison, A. (2003). The elderly offender: An 11-year survey of referrals to a regional forensic psychiatric service. Journal of Forensic Psychiatry \& Psychology, 14(2), 253-265. https://doi.org/10.1080/1478994031000077989

Davis, B., Maclagan, M., \& Shenk, D. (2016). The silent violence of marginalization and teasing in dementia care residences. Journal of Language Aggression and Conflict, 4(1), 35-61.

Fazel, S., \& Grann, M. (2002). Older criminals: A descriptive study of psychiatrically examined offenders in Sweden. International Journal of Geriatric Psychiatry, 17(10), 907-913. https://doi.org/10.1002/gps.715

Fazel, S., Hope, T., O’Donnell, I., \& Jacoby, R. (2002). Psychiatric, demographic and personality characteristics of elderly sex offenders. Psychological Medicine, 32(2), 219-226.

https://doi.org/10.1017/S0033291701005153

Fazel, S., O'Donnell, I., Hope, T., Gulati, G., \& Jacoby, R. (2007). Frontal lobes and older sex offenders: A preliminary investigation. International Journal of Geriatric Psychiatry, 22(1), 87-89.

\section{https://doi.org/10.1002/gps.1648}

Federal Bureau of Prisons (2019). United States Department of Justice: Federal Prison System performance budget. Washington, DC: Federal Bureau of Prisons

Feldmeyer, B. and Steffensmeier, D. (2007) Elder Crime: Patterns and Current Trends, 1980-2004. Research on Aging, 29, 297-322. https://doi.org/10.1177/0164027507300802 Gal, M. (2003). The physical and mental health of older offenders. Mental Health, 38, 17-2. Goetting, A. (1984). 'The elderly in prison: a profile', Criminal Justice Review, 9, 14-24. Greene, E., \& Gibson, S. C. (2013). The Experiences of Older Adults in the Legal System. In M. Miller and B. Bornstein, Stress, Trauma, and Wellbeing in the Legal System. United States, Oxford Scholarship Online. https://doi.org/10.1093/acprof:oso/9780199829996.003.0007

Gross, B. (2007). Elderly offenders: Implications for corrections personnel. The Forensic Examiner, 16(1), 56-61. Retrieved from http://search.ebscohost.com/login.aspx?direct=true\&AuthType=ip, shib,cpid\&custid=s6264444\&db= psyh\&AN=2007-04268-005\&site=ehost-live \&scope=site

Hayes, A. J., Burns, A., Turnbull, P., \& Shaw, J. J. (2013). Social and custodial needs of older adults in prison. Age and ageing, 42(5), 589-593.

Howse, K. (2011). Gorwing older in prison: A scoping study on older prisoners. Centre for Policy on Ageing and Prison Reform Trust. 
Hunt, I. M., Swinson, A. B. N., Flynn, S., Hayes, A. J., Roscoe, A., Rodway, C., ... Shaw, J. (2010). Homicide convictions in different age-groups: A national clinical survey. Journal of Forensic Psychiatry and Psychology, 21(3), 321-335. https://doi.org/10.1080/14789940903513195 Ishihara, J., \& Kempf-Leonard, K. (2009). Exploring factors affecting the aging prison population in Japan. ProQuest Dissertations and Theses. Southern Illinois University at Carbondale, Ann Arbor. Retrieved from https://search.proquest.com/docview/304996355?accountid=14685 Kerbs, J. J., \& Jolley, J. M. (2007). Inmate-on-inmate victimization among older male prisoners. Crime \& Delinquency, 53(2), 187-218.

Kingston, P., Le Mesurier, N., Yorston, G., Wardle, S., \& Heath, L. (2011). Psychiatric morbidity in older prisoners: unrecognized and undertreated. International Psychogeriatrics, 23(8), 1354-1360. Lemieux, C. M., Dyeson, T. B., \& Castiglione, B. (2002). Revisiting the literature on prisoners who are older: Are we wiser?. The Prison Journal, 82(4), 440-458.

Loeb, S. J., Steffensmeier, D., \& Kassab, C. (2011). Predictors of self-efficacy and self-rated health for older male inmates. Journal of advanced nursing, 67(4), 811-820.

Merten, M. J., Bishop, A. J., \& Williams, A. L. (2012). Prisoner health and valuation of life, loneliness, and depressed mood. American journal of health behavior, 36(2), 275-288.

Ministry of Justice (2018). Offender management statistics quarterly: January to March 2018. London: Ministry of Justice.

Ministry of Justice, Statistics Bureau of Japan (2016). Annual Report of Statistics on Corrections (2016). Tokyo: Ministry of Justice http://hakusyo1.moj.go.jp/en/66/nfm/n 6622241 3.html Munday, D (2017) Health and social care needs assessments of the older prison population. London: Public Health England.

NACRO (2009). Foreign national offenders, mental health and the criminal justice system. London: NACRO.

Naikakufu (2009). Shōshika shakai hakusho (Heisei 21-nen ban) [(2009) white book on low fertility]. Tokyo: Naikakufu.

O'Hara, K., Forsyth, K., Webb, R., Senior, J., Hayes, A. J., Challis, D., ... \& Shaw, J. (2016). Links between depressive symptoms and unmet health and social care needs among older prisoners. Age and ageing, 45(1), 158-163.

Overshott, R., Rodway, C., Roscoe, A., Flynn, S., Hunt, I. M., Swinson, N., ... Shaw, J. (2012). Homicide perpetrated by older people. International Journal of Geriatric Psychiatry, 27(11), 1099-1105.

Retrieved from http://search.ebscohost.com/login.aspx?direct=true \&db=pbh\&AN=82212127\&site=ehost-live 
Peden, J., McCann, L. O'Moore, E., Phipps, E., Ford, T., Plugge, ... Connolly, A.M. (2018). Gender Specific Standards to Improve Health and Wellbeing for Women in Prison in England. Public Health England https://assets.publishing.service.gov.uk/government/uploads/system/uploads/attachment data/file/687146/Gender specific standards for women in prison to improve health and wellb eing.pdf

Petersen, D. (1988) Substance Abuse, Criminal Behavior, and Older People. Journal of the American Society on Aging, 12, 63-67.

Prison Reform Trust (2019). Bromley briefings prison factfile: Winter 2019. London.

Prison Reform Trust (2008). Doing Time: the experiences and needs of older people in prison. $A$ Prison Reform Trust briefing.

Prison Reform Trust (2018). Prison: the facts. Bromley briefings: Summer 2018. London.

Putkonen, H., Weizmann-Henelius, G., Repo-Tiihonen, E., Lindberg, N., Saarela, T., Eronen, M. and Hakkanen-Nyholm, H. (2010). Homicide, psychopathy, and aging - a nationwide register-based casecomparison study of homicide offenders aged 60 years or older. Journal of Forensic Sciences, 55, 1552-1556. https://doi.org/10.1111/j.1556-4029.2010.01488.x

Reutens, S., Nielssen, O., \& Large, M. (2015). Homicides by older offenders in New South Wales between 1993 and 2010. Australasian Psychiatry, 23(5), 493-495.

\section{https://doi.org/10.1177/1039856215579525}

Rodriguez, M., Boyce, P., \& Hodges, J. (2017). A neuropsychological study of older adult first-time sex offenders. Neurocase (Psychology Press), 23(2), 154-161.

https://doi.org/10.1080/13554794.2017.1334802

Stanback, B., \& King-Kallimanis, B. L. (2011). Older offenders and homicide: What can we learn from the Chicago Homicide Dataset? Homicide Studies: An Interdisciplinary \& International Journal, 15(1), 32-47. https://doi.org/10.1177/1088767910397272

Stevens, B. A., Shaw, R., Bewert, P., Salt, M., Alexander, R., \& Loo Gee, B. (2018). Systematic review of aged care interventions for older prisoners. Australasian journal on ageing, 37(1), 34-42.

Trotter, C., \& Baidawi, S. (2015). Older prisoners: Challenges for inmates and prison management. Australian \& New Zealand Journal of Criminology, 48(2), 200-218.

Whittemore, R., \& Knafl, K. (2005). The integrative review: updated methodology. Journal of advanced nursing, 52(5), 546-553.

Wilkinson, D. J., \& Caulfield, L. S. (2017). The perceived benefits of an arts project for health and wellbeing of older offenders. Europe's journal of psychology, 13(1), 16.

Williams, B. A., Goodwin, J. S., Baillargeon, J., Ahalt, C., \& Walter, L. C. (2012). Addressing the aging crisis in US criminal justice health care. Journal of the American Geriatrics Society, 60(6), 1150-1156. 
Williams, M. E., \& Rikard, R. V. (2005). Marginality or neglect: An exploratory study of policies and programs for aging female inmates. Women and Criminal Justice, 15(3-4), 121-141.

https://doi.org/10.1300/J012v15n03_06

Wong, M.T., Lumsden, J., Fenton, G.W. and Fenwick, P.B. (1995). Elderly Offenders in a MaximumSecurity Mental Hospital. Aggressive Behavior, 21, 321-324. https://doi.org/10.1002/1098-2337 Yorston, G. A. (2010). The Elderly Offender. In Principles and Practice of Geriatric Psychiatry: Third Edition (pp. 694-699). St Andrew's Hospital, Northampton NN1 5DG, United Kingdom.

https://doi.org/10.1002/9780470669600.ch110 
Appendix A List of databases searched and results

\begin{tabular}{|c|c|c|}
\hline CINAHL complete & $1992-2018$ & 196 \\
\hline Cochran Library & 2001-2016 & 14 \\
\hline ERIC & $1967-2018$ & 62 \\
\hline Europe PubM $\_$Central & 2014-2018 & 68 \\
\hline MEDLINE & $1948-2018$ & 46 \\
\hline PsycARTICLES & $1934-2018$ & 12 \\
\hline PsycINFO & 1923-2018 & 159 \\
\hline SAGE Complete A-Z Lir'. & $1924-2018$ & 181 \\
\hline ScienceDirect Journals & $1995-2018$ & 561 \\
\hline Scopus & $2010-2019$ & 380 \\
\hline ProQuest Central & & 366 \\
\hline Web of Science & $1, \cdot 8-2018$ & 78 \\
\hline Social Care online & $\left.199^{\prime},-\angle U_{\perp}\right\}$ & 74 \\
\hline CINAHL Plus with Full Text & $\begin{array}{l}\text { Nu } \text {-ing a'id allied health journals } \\
\text { 1992-201` }\end{array}$ & 199 \\
\hline Medline with full text & $\begin{array}{l}\text { Medicine and }{ }^{\prime}=\text { althcare } \\
\text { 1948-2018 }\end{array}$ & 306 \\
\hline $\begin{array}{l}\text { Psychology and Behavioral } \\
\text { Sciences Collection }\end{array}$ & $\begin{array}{l}\text { Emotional and b } \epsilon^{\prime} \text {,avic } \text { ral characteristics. } \\
\text { 1971-2018 }\end{array}$ & 91 \\
\hline SocINDEX with Full Text & $\begin{array}{l}\text { Sociological research } \\
1975-2017\end{array}$ & 67 \\
\hline Cambridge core & $\begin{array}{l}\text { Digitised backfiles of Science, Tecl nulogy and Medicine } \\
\text { journals, and Humanities \& Social Sr .enres journals from } \\
\text { Cambridge University Press }\end{array}$ & 1 \\
\hline JSTOR & $\begin{array}{l}\text { JSTOR is a digital library of academic journals, books, and } \\
\text { primary sources. JSTOR helps people discover, use, and } \\
\text { build upon a wide range of content through a powerful } \\
\text { research and teaching platform, and preserves this } \\
\text { content for future generations. }\end{array}$ & 9 \\
\hline PubMed & $\begin{array}{l}\text { biomedical literature from MEDLINE, life science journals, } \\
\text { and online books }\end{array}$ & 34 \\
\hline ProQuest & $\begin{array}{l}\text { A broad range of full-text and bibliographic databases } \\
\text { hosted by Proquest } \\
\text { Included: Dissertations and theses; Scholarly journals; } \\
\text { Books; Working papers; Trade journals }\end{array}$ & 463 \\
\hline
\end{tabular}


Journal of Criminal Psychology

Page 36 of 75

$$
\begin{aligned}
& 1 \\
& 2 \\
& 3 \\
& 4 \\
& 5 \\
& 6 \\
& 7 \\
& 8 \\
& 9 \\
& 10 \\
& 11 \\
& 12 \\
& 13 \\
& 14 \\
& 15 \\
& 16 \\
& 17 \\
& 18 \\
& 19 \\
& 20 \\
& 21 \\
& 22 \\
& 23 \\
& 24 \\
& 25 \\
& 26 \\
& 27 \\
& 28 \\
& 29 \\
& 30 \\
& 31 \\
& 32 \\
& 33 \\
& 34 \\
& 35 \\
& 36 \\
& 37 \\
& 38 \\
& 39 \\
& 40 \\
& 41 \\
& 42 \\
& 43 \\
& 44 \\
& 45 \\
& 46 \\
& 47 \\
& 48 \\
& 49 \\
& 50 \\
& 51 \\
& 52 \\
& 53 \\
& 54 \\
& 55 \\
& 56 \\
& 57 \\
& 58 \\
& 59
\end{aligned}
$$




\section{Appendix B Search Strings Used in Literature Searches}

\begin{tabular}{|c|c|c|c|}
\hline & Search Topic & Search Terms ${ }^{a}$ & $\begin{array}{l}\text { Search } \\
\text { Field }\end{array}$ \\
\hline 1 & Older $\mathrm{O}^{f^{\prime}}$ ender & $\begin{array}{l}\text { Older offender OR Elderly Offender OR Older prisoner OR Elderly Prisoner OR } \\
\text { Aging Prisoners OR Aging Offenders OR Geriatric offender OR Geriatric } \\
\text { orisoner OR Prisoner over AGE OR Offender over AGE } \\
\text { vider offender" OR "Elderly Offender" OR "Older prisoner" OR "Elderly } \\
\text { riso ier" OR "Aging Prisoners" OR "Aging Offenders" OR "Geriatric offender" } \\
\text { OR "viri ttric prisoner" OR "Prisoner over AGE" OR "Offender over AGE" }\end{array}$ & All text \\
\hline 2 & Health & Health OR Well-being OR Psycholog* OR Psyc* & All text \\
\hline 3 & Violence & $\begin{array}{l}\text { Violen* OR Aggressive OR Domestic OR intimate partner violence OR } \\
\text { Deviance OR Antisocial }\end{array}$ & All text \\
\hline 4 & Needs & Criminogenic Needs OR supportive needs & All text \\
\hline 5 & Risk & $\begin{array}{l}\text { Risk assessment OR Crime committed OR Offence type (sub-search terms } \\
\text { needed??) Or Violence OR Violent offence Or Sexual offence OR First offence } \\
\text { OR First timer }\end{array}$ & All text \\
\hline 6 & $\begin{array}{l}\text { Offender } \\
\text { typology }\end{array}$ & Life course persistent OR First-time older OR Repeat offender & All text \\
\hline 7 & $\begin{array}{l}\text { Intervention or } \\
\text { cause }\end{array}$ & $\begin{array}{l}\text { Characteristics OR Dementia OR Mental health (under 'causes' rather than } \\
\text { needs) OR Mental illness OR Ageing population OR Growing old OR Longer } \\
\text { sentences OR Indeterminate sentence OR Historic }\end{array}$ & All text \\
\hline
\end{tabular}




\section{Appendix C PRISMA}

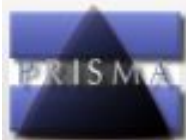

\section{Amended PRISMA 2009 Flow Diagram}

Records identified through database searching entered into Mendeley

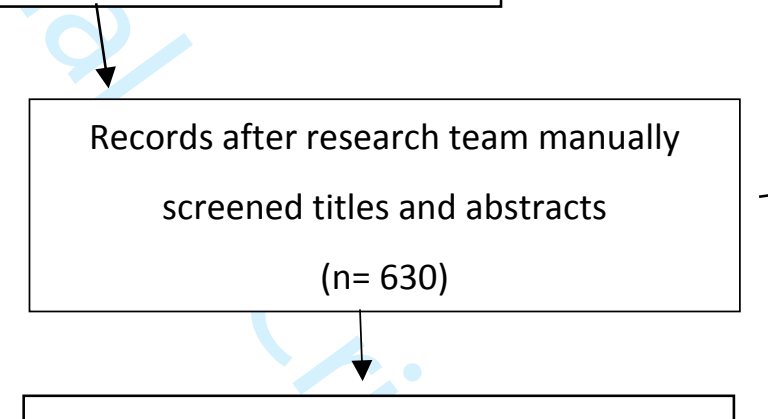

Records after duplicates removed $(n=594)$

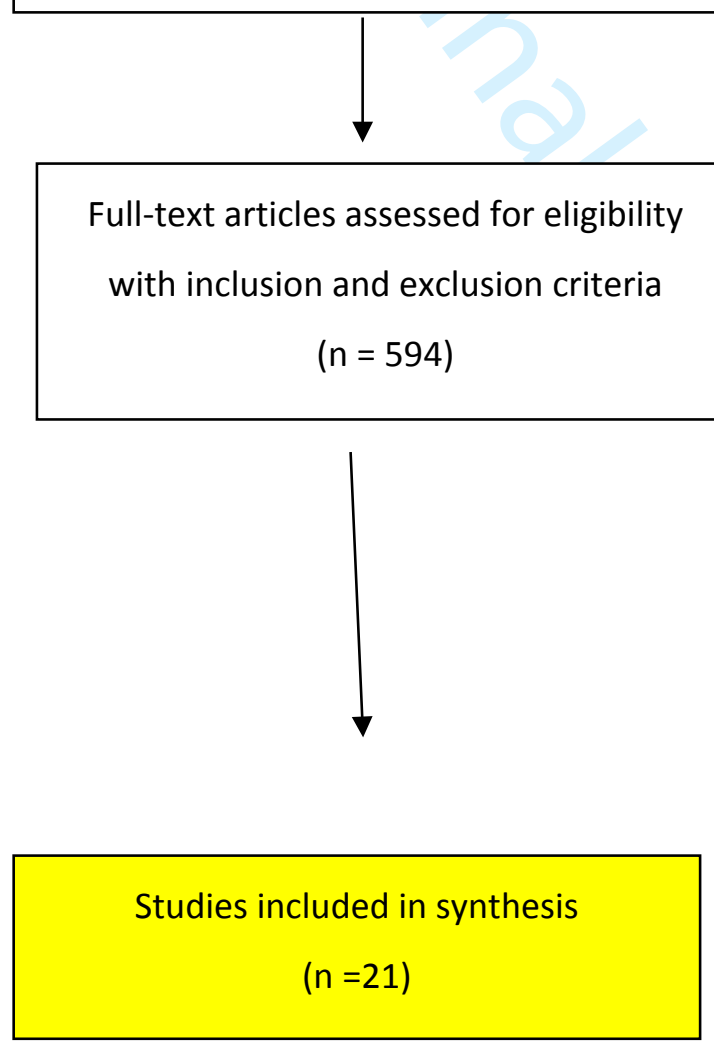

Records excluded ( $n=3258)$ manual screening to remove papers without Older Offender terms in title,

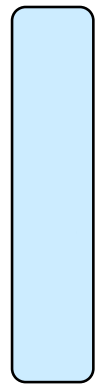




\title{
A systematic review of the-offending characteristics and needs of older prisoners
}

\begin{abstract}
Purpose

The older prisoner population is growing faster than the older general population and displays high levels of physical and mental health needs, placing a strain on prisons. Much of the existing

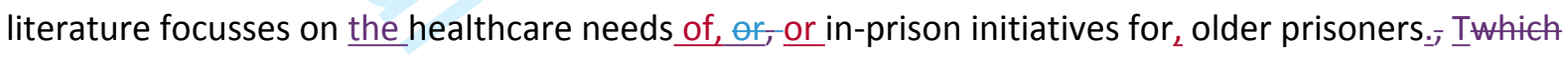
are typically, these are responsive father than evidence-based and systematically planned ${ }_{L}$ and thoroughly grounded in an evidence-basedincorporating and lacking an evidence-based understanding of the characteristics and needs of this group. There is a need to review and understand what the existing evidence base concludes about the needs of this population.
\end{abstract} Design/methodology/approach

This paper presents a systematic review of the existing literature on the needs and characteristics ofolder older ppeople in contact with the criminal justice systemrisoner characteristics. After a thorough search and slectionselection process, 21Twenty one papers, from 2002 onwards, were included in the final analysisexisting literature from 2002 onwards. The review process was; structured through PICOs and reported using PRISMA.

Findings

The existing evidence suggests captured some offending characteristics of certain groups of that older prisoners, are such as anthe increasedmore likelihood ofto committing crimes against the person $n_{L}$ that are physical orand sexual in nature when compared to younger prisoners. I, the evidence also suggests that theirir crimes are more likely to be linked to alcohol misuse and abuse. However, our current findings are limited by sample demographics and methodologies and therefore cannot be assumed to apply to all older prisoners.

The contradictions within the existing evidence base make it difficult to reach firm conclusions about the needs and characteristics of older prisoners. What is clear from the existing research are the relatively high levels of need. There is also some consensus that where older people commit homicide the victim is likely to be an intimate partner. Overall, there a need for consistent recording and reporting of characteristics and demographics and more systematic study design.

\section{Originality/value}


This paperroject has highlighted-some of the key-findings and limitations in the existing literaturekey factors and findings from the existing published evidence on older prisoners. Future research should make use of secondary official data sources to provide a clearer understanding of the characteristics of this group, their routes to prison, their needs, and challenges they present.

\section{Keywords}

\section{Elderly Prisoner; Older Prisoner; Characteristics; Older Offender}

This research did not receive any specific grant from funding agencies in the public, commercial, or not-for-profit sectors.

\subsection{Introduction}

\subsection{The ageing prison population: an international issue}

Across the world, the prison population is ageing. In the United States, for example, the number of prisoners over age 55 increased by 181\% between 2000 and 2010_Bureau of Justice Statistics 19902010). This is compared to an increase in the overall US prison population of $17 \%$ during the same time period (Williams, Goodwin, Baillargeon, Ahalt \& Walter, 2012). The most recent 2019 datadata ${ }_{\overline{\text { II }}}$ from 2019 , show thats $19.2 \%$ of the current US prison population are 50 years and over (Federal Bureau of Prisons, 2019). The same pattern appears to be emerging in the Asia Pacific region: for example, the Philippines saw the older prisoner group increase from $2 \underline{8} 7.89 \%$ to $4 \underline{3} z .88 \%$ of the prison population between 2002 and 2014 (Bureau of Corrections \& Philippine Statistics Authority, 2015). Baidawi et al. (2011) highlight that in Australia the older prisoner population growth has been much greater than the general older population growth, a pattern mirrored in many other countries. - In 2009, Japan had one of the highest proportions of older people in prison (Naikakufu, 2009; Ishihara \& Kempf-Leonard, 2009) and in 2016 people over 50 years contributed $35.3 \%$ of new male prisoners and $38.9 \%$ of new female prisoners (Ministry of Justice, Japan, 2016). In England and Wales, the number of prisoners aged fifty and over increased by $200 \%$ in the decade to 2018 and those age 40-49 increased by around 75\% (Ministry of Justice, UK, 2018). -In comparison, over the same time period, the number of prisoners in England and Wales age 21-29 decreased, while those age 30-39 remained roughly the same (Ministry of Justice, UK, 2018). The definition of 'older', when referring to individuals in the criminal justice system, is inconsistent in the research literature. -However, increasingly researchers are considering individuals as young as fifty as 'older' in criminal justice settings (e.g. Gal, 2003; Aday \& Krabill, 2013zz; Wilkinson \& 
Caulfield, 2017). Research examining the prison population notes the accelerated ageing process and high levels of cognitive decline, compared to the general population (Stevens et al., 2018; Davis, Maclagan \& Shenk, 2016) and the rise in older prisoners is problematic for a number of reasons. -An increase in this group raises questions about the appropriateness and effectiveness of current prison regimes (Baidawi et al., 2011; Trotter \& Baidawi, 2015), which are typically designed to be suitable for younger adults. Wilkinson and Caulfield (2017) note that, in prisons in England and Wales, there is often a lack of meaningful activity suitable for older prisoners. This could contribute to the onset of cognitive decline, with which can come increased levels of violence (Davis, Maclagan \& Shenk, 2016). Concerns have also been raised about the prevalence of mental and physical health problems in older prisoners (Lemieux et al., 2002), and the resource implications of supporting these needs (Canada et al., 2019; O’hara et al., 2016).

\subsection{The characteristics and needs of older prisoners}

Some research has sought to explore the characteristics of older prisoners. Lemieux et al (2002) presented trends from US data, noting that older prisoners tended to be unmarried, white, male, employed prior to incarceration, but never graduated from high school. Older prisoners were either career criminals (prison recidivists), old offenders (first incarceration-occurred at age 55 or older), first offenders (first incarceration before the age of 55), or 'old-timers' (growing old in prison)these categories were first highlighted by Goetting (1984). While it has been argued that the older population in prison can be vulnerable and subject to victimisation (Baidawi, Trottter \& Flynn, 2016, Wilkinson \& Caulfield, 2017), Lemieux et al (2002) found evidence to support that older people were likely to be arrested for aggravated assault, larceny theft, sex offences, and homicide, challenging assumptions about vulnerability. Recent research supports this, with violent crimes in the older population increasing in prevalence in the UK (The Prison Reform Trust, 2018). There is evidence that older people are more likely than younger people to be arrested for alcohol and drug-related matters (Garabellese et al., 2012; Putkonen et al., 2010; Peterson, 1998; Wong, Lumsden, Fenton and Fenwick, 1995) and crimes against the person (Feldmeyer \& Steffensmeier, 2007). In England and Wales, the majority of older males in prison have committedare more likely to be serving a sentence for offences that are sexual in nature (45\% of all older men in prison) and/or violence against the person (23\% of all older men in prison) than any other offence type (Prison Reform Trust, 2019)., leading to $80 \%$ of individuals serving a sentence of four or more years (Wilkinson \& Caulfield, 2017Bromley Briefing, 2017).

As noted above, with the increase in older prisoners comes an increase in the prevalence of mental and physical health Issues. Commonly reported illnesses issues are psychiatric, cardiovascular, 
musculoskeletal and respiratory (Prison Reform Trust, 2008; Howse, 2011). Older offenders typically have a high prevalence of chronic health conditions (Merten, Bishop \& Williams, 2012; Fazel, et al., 2002) including $9 \%$ with mobility issues reported by Fazel, et al. (2002). - In the United Kingdom, a Department of Health survey (1999-2000) highlighted that $85 \%$ of prisoners aged 60 and over had one or more major illnesses reported in their medical records, while $83 \%$ reported at least one chronic illness or disability. Mental health issues are thought to affect half of this population with many individuals experiencing depression arising as a result of imprisonment (Merten, Bishop \& Williams, 2012). Despite these figures, mental health issues are often overlooked by those in contact with the older population (Kingston, Mesurier, Yorston, Wardle \& Heath, 2011).

Much of the literature has focused on in-prison initiatives for older prisoners, which are typically responsive rather than systematically planned and thoroughly grounded in an evidence-based understanding of the characteristics and needs of this group (Caulfield \& Wilkinson, 2017). The international rise in the older prison population and the challenges posed by this suggests a need to thoroughly review what the research literature to date has said about the needs and characteristics of this group. A better and more coordinated understanding of older prisoners could: a) guide the development of regimes that are less reactive and support the specific needs of older offenders, including the need for meaningful activities while in prison (Hayes, Burns, Turnbull, and Shaw, 2013; NACRO, 2009; Wilkinson \& Caulfield, 2017); b) allow for fuller consideration of the risk profile of this group; and c) provide evidence to support the development of appropriate assessment and treatment.

The aim of this paper is to systematically search the literature to select and review all existing and relevant studies that explore the effending-needs and characteristics of older prisoners _ using $\underline{50}$ years and over to be inclusive of the variety of definitions found in theliterature), excluding their inprison programme experiences.

\section{Research Question}

What are the-offending characteristics and needs of older prisoners?

\subsection{Method}

\subsection{Search Strategy}

Databases (see appendix A) were searched using the search terms and strings outlined in appendix B. A total of $\mathbf{3 8 8 8}$ papers were imported into Mendeley from the database searches. The research team manually screened the titles and abstracts of the imported papers against the basic search criteria, reducing the total relevant papers to 630 . Duplicates were automatically removed by Mendeley using paper title, author(s), and year order, leaving a total of $\mathbf{6 0 8}$ papers. The research 
team manually searched and removed further duplicates by author, leaving $\mathbf{5 9 4}$ papers. Twelve of these were book reviews and two were tender documents, therefore they were also removed. The research team removed 146 papers due to publication date being before 2001 as - based on Public Health England statistics (Munday, 2017), US data (Gross, 2007), and reporting on global prison trends (Allen, 2015) - 2002 is when the significant rise in older offenders began. This left $\mathbf{4 3 3}$ papers.

\subsection{Selection Criteria}

The inclusion and exclusion criteria (see below) were discussed in relation to the research aim, and the research team looked through a sample of studies together as an early moderation exercise to check the application of inclusion and exclusion criteria before performing the exercise. Using Mendeley, two researchers applied the inclusion and exclusion criteria by marking the remaining 433, indicating the papers that focused on the general needs and characteristics of the population and removal of papers that focused on health and social care/ in prison treatment or intervention programmes. The researchers assessed half of the maing papers and moderated other's reviews. Asample of twentypapers, ten fromeach researcher, wereview in the early moderation poss. The paper by toe al. (2011) is a exampleof a paper that some mention of characteristics but focussed primarily on in prison health care management factors and Pasers that focussed solely on prisoner care or treatmenttreatment or interventions were excluded as the this current systematic review focuses on needs and characteristics rather than treatment programmes and their effectiveness. $\mathrm{H}$, however, papers containing substantial information about prison or forensic assessments did remain (e.g. Fazel \& Grann, 2002) as these papers could contain insight information regarding the characteristics of older prisoners. The researchers assessed half of the remaining papers each and moderated each other's reviews. A sample of 20 twenty papers, ten from each researcher, were reviewed in the early moderation process. The paper by Loeb et al. (2011) is an example of a paper that had some mention of characteristics but focussed primarily on in-prison health care management factors and therefore was excluded.

After the sifting exercise $\mathbf{5 4}$ papers remained for full text review. After full text review, and the application of the inclusion and exclusion criteria, $\mathbf{3 0}$ papers remained, but a further nine were removed upon discussion due to the focus and nature of the papers. One of these two papers was a short commentary review and the other described a new model of working in Japan. See PRISMA diagram (appendix C) for more information about the removed and remaining papers.

\subsection{Inclusion and Exclusion Criteria}


Include

Literature reviews

Papers in English language

Demographic information on the older offending

population $^{1}$

Characteristics and needs of the older offending population $^{2}$

$\underline{\text { Studies with assessment data }}$

\subsection{Data extraction and analysis}

The remaining $\mathbf{2 1}$ papers were analysed and synthesised drawing on an approach similar to that proposed by Whittemore and Knafl (2005) of data reduction, data display, data comparison, and verification of conclusions. This approach was most suitedappropriate given the ethos of a review method that is inclusive of_combining-diverse study methodologies (e.g. interviews, focus group, survey data with quantitative data). -This procedure allowed for the process of identifying patterns, which were then grouped together to form the overarching themes.

\subsection{Results}

Table 1.0 shows that of the 21 papers included in this review, seven were review papers, four were primary empirical studies, and 10 papers presented analysis of existing data sets. Table 1.0 presentsFor more information about types of papers and samples included (e.g. country of origin). Table 1.1 presents- a summary of the key information and findings from each paper relevant to the research question: What are the characteristics and needs of older prisoners?.-Six papers were from the United Kingdom (two review papers; one primary data; three secondary data); three papers

\footnotetext{
${ }^{1}$ Older offending generally, as opposed to only older prisoners. The research team identified that research on needs and characteristics has not only looked at prison groups, and so excluding studies focused on arrest data, for example, may exclude important learning

$2 \underline{\text { In this systematic review }}$ paper we use the terms needs and characteristics in a broad sense to include information or health (including mental health), historical information presented about older prisoner's lives, criminogenic needs, current offence type, offending history background. The inclusion criteria referring to needs and characteristics were purposely

\section{Exclude}

NPapers in any other language (non-English language-

Introductory topic overviews

Health and social care responses/treatment

Papers capturing solely in-prison experiences

Papers presenting solely reasons for the rise

in this population 
were from Australia (one review paper; one primary data; one secondary data); one paper was from France (secondary data); six papers were from the USA (two review papers; one primary data; three secondary data); one paper was from Canada (one review paper); one paper was from New Zealand (review paper); two papers were from Sweden (one primary data; one secondary data); and one paper was from Finland (secondary data). 


\section{[Insert Table 1.0 outline of papers included]}

Table 1.1 Summary of $k f, f$ findings from the studies included in this review

\begin{tabular}{|c|c|c|c|}
\hline ReferenceEF & $\begin{array}{l}\text { Paı ucir ants } \\
\text { population s }<\mathrm{e}\end{array}$ & Key findings / argument & Key discussion points \\
\hline $\begin{array}{l}\text { Baidawi, Turner, } \\
\text { Trotter, } \\
\text { Browning, } \\
\text { Collier, Connor } \\
\text { \& Sheehan } \\
\text { (2011) }\end{array}$ & $\begin{array}{l}\text { - } \quad \text { Review pape. } \overline{/ p} \text {, sitı in paper } \\
\text { - } \quad \text { Older people }(50+)\end{array}$ & $\begin{array}{l}\text { - Makes a case that defining the 'older prisoner' is essential in order } \\
\text { to do comparative research and a lack of clarity can impeded a firm } \\
\text { evidence based being formed around related issues, for example, } \\
\text { off-.-re types, recidivism rates, health concerns and prison } \\
\text { management programs. Claims for the rise in the older prison } \\
\text { population due to policy and practice; release and resettlement } \\
\text { issues; vulnerability and victimisation; suitability of prison regime, } \\
\text { nursing home prisons, hospices and special needs units; staffing, } \\
\text { services and programs; heightened caution with regards to parole } \\
\text { and reduced cases of early release. } \\
\text { It makes a case for further complexity of minority groups within the } \\
\text { older population (e.g. females and indigenous in the AUS } \\
\text { population). }\end{array}$ & $\begin{array}{l}\text { Highlights the issues of defining older offenders } \\
\text { and the rise in older prison populations (AUS } \\
\text { based). It makes a case for further complexity } \\
\text { of minority groups within the older offender } \\
\text { population (e.g. females and indigenous in the } \\
\text { AUS population). The paper considered the } \\
\text { eosts of responding to the health care needs, } \\
\text { accommodation and correctional programs } \\
\text { involved, suggesting implications to policy } \\
\text { makers. }\end{array}$ \\
\hline $\begin{array}{l}\text { Beaufrère, } \\
\text { Belmenouar \& } \\
\text { Chariot (2014) }\end{array}$ & $\begin{array}{l}\text { Assessment ofSample of } 180(1 \% \\
\text { of total arrest records } 15,481) \\
\text { Oolder peorople in police } \\
\text { custody }(60+) \text { arrested in police } \\
\text { custody cells. } \\
92 \% \text { male and } 8 \% \text { female }\end{array}$ & $\begin{array}{l}\text { The proportion of detainees arrested twice or more during the } \\
\text { studied year was smaller in detainees over } 60 \text { than in those under } \\
60 . \\
\text { drunk driving }(38,24 \%) \text {, threats }(15,10 \%) \text {, driving without a license } \\
(12,8 \%) \text {, thefts or robberies }(8,5 \%) \text {, sexual assaults }(7,4 \%) \text {, fraud }\end{array}$ & $\begin{array}{l}\text { Notes the prevalence of arrests in the over } 60+\text {, } \\
\text { utilising medical records. The paper discusses } \\
\text { the implications of health declining with age } \\
\text { and therefore the considerations to be made } \\
\text { with regards to being 'less fit' for detention. }\end{array}$ \\
\hline
\end{tabular}




\begin{tabular}{|c|c|c|c|}
\hline & 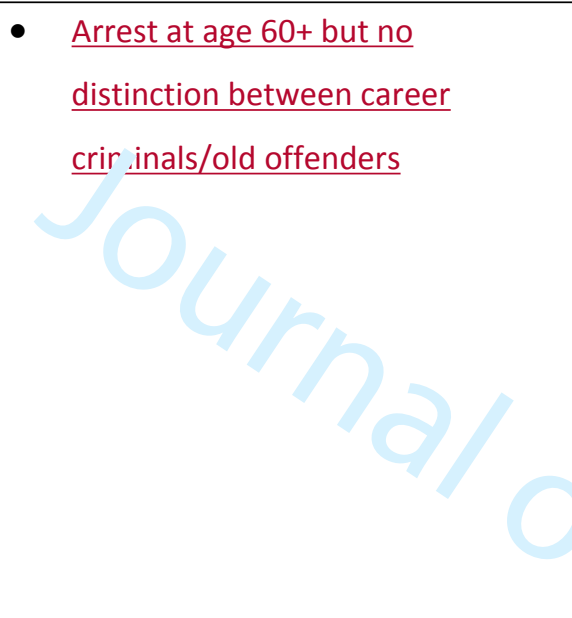 & $\begin{array}{l}\text { (6, } 4 \%) \text {, damage to private property }(6,4 \%) \text {, carrying weapons ( } 6 \text {, } \\
4 \%) \text {, traffic accidents }(5,3 \%) \text {, and breach of legislation on } \\
\text { foreigners }(4,3 \%) \text {. } \\
\text { Among cases of physical assaults, } 12 \text { of } 51(24 \%) \text { were related to } \\
\text { domestic violence. In } 23 \text { of } 180 \text { cases }(13 \%) \text {, the suspected crime } \\
\text { was unknown. } \\
\text { A total of } 78 \text { of } 170(46 \%) \text { expressed some complaints during } \\
\text { medical examination, which included pain ( } 54 \text { of } 170,32 \%) \text {, } \\
\text { psychological symptoms ( } 10 \text { of } 170,6 \%) \text {, fatigue ( } 9 \text { of } 170,5 \%) \text {, } \\
\text { reathing difficulties ( } 4 \text { of } 170,2 \%) \text {, and hunger ( }(3 \text { of } 170,2 \%) \text {. }\end{array}$ & \\
\hline Block (2013) & 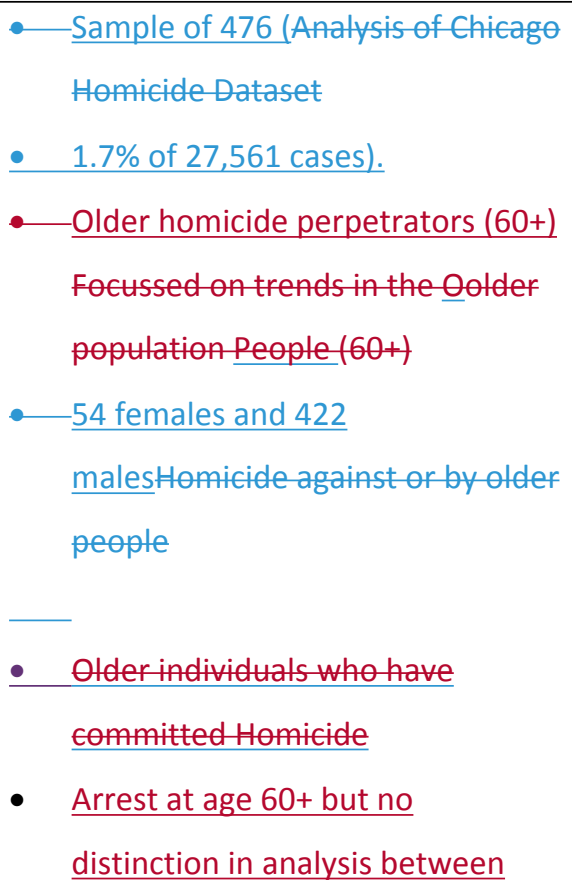 & 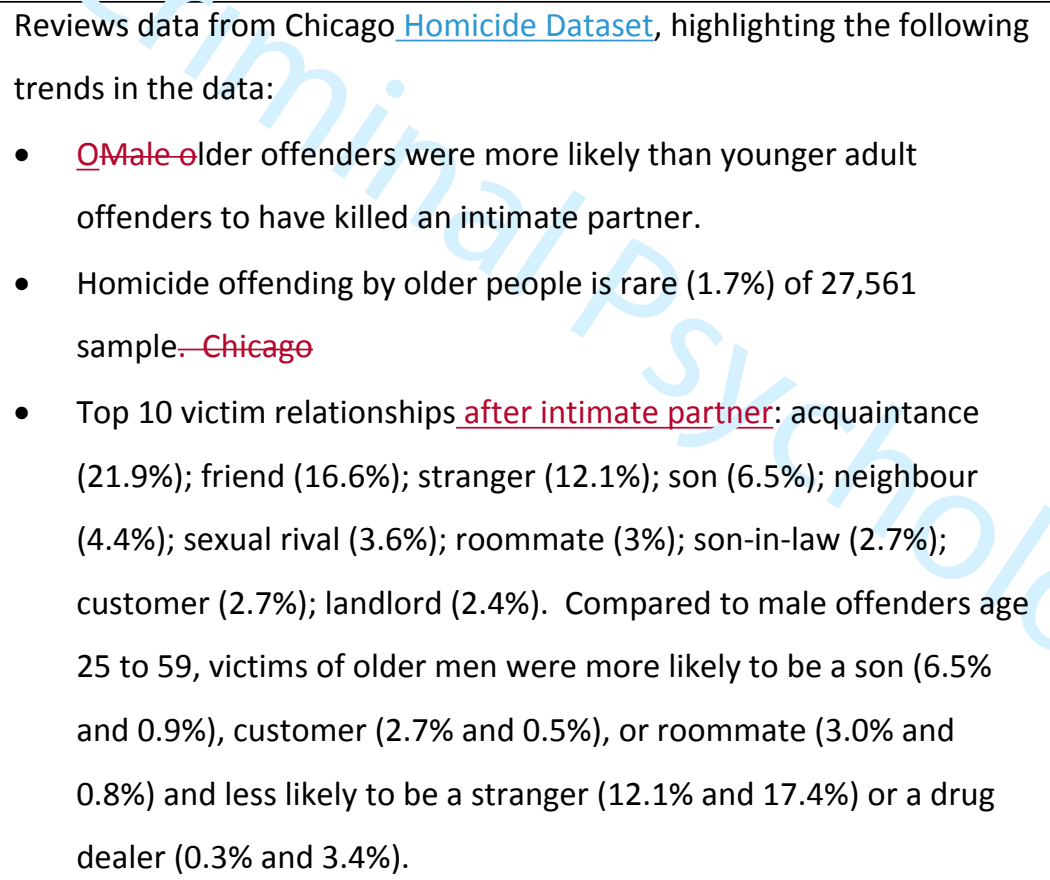 & $\begin{array}{l}\text { Discusses the older offender and victim } \\
\text { relationship (in intimate partner cases). This } \\
\text { paper suggests that older people are less likely } \\
\text { to have prior violent offence records, but do } \\
\text { have higher suicide rates and are more likely to } \\
\text { commit homicide alone. }\end{array}$ \\
\hline
\end{tabular}




\begin{tabular}{|c|c|c|c|}
\hline & career criminals/old offenders & 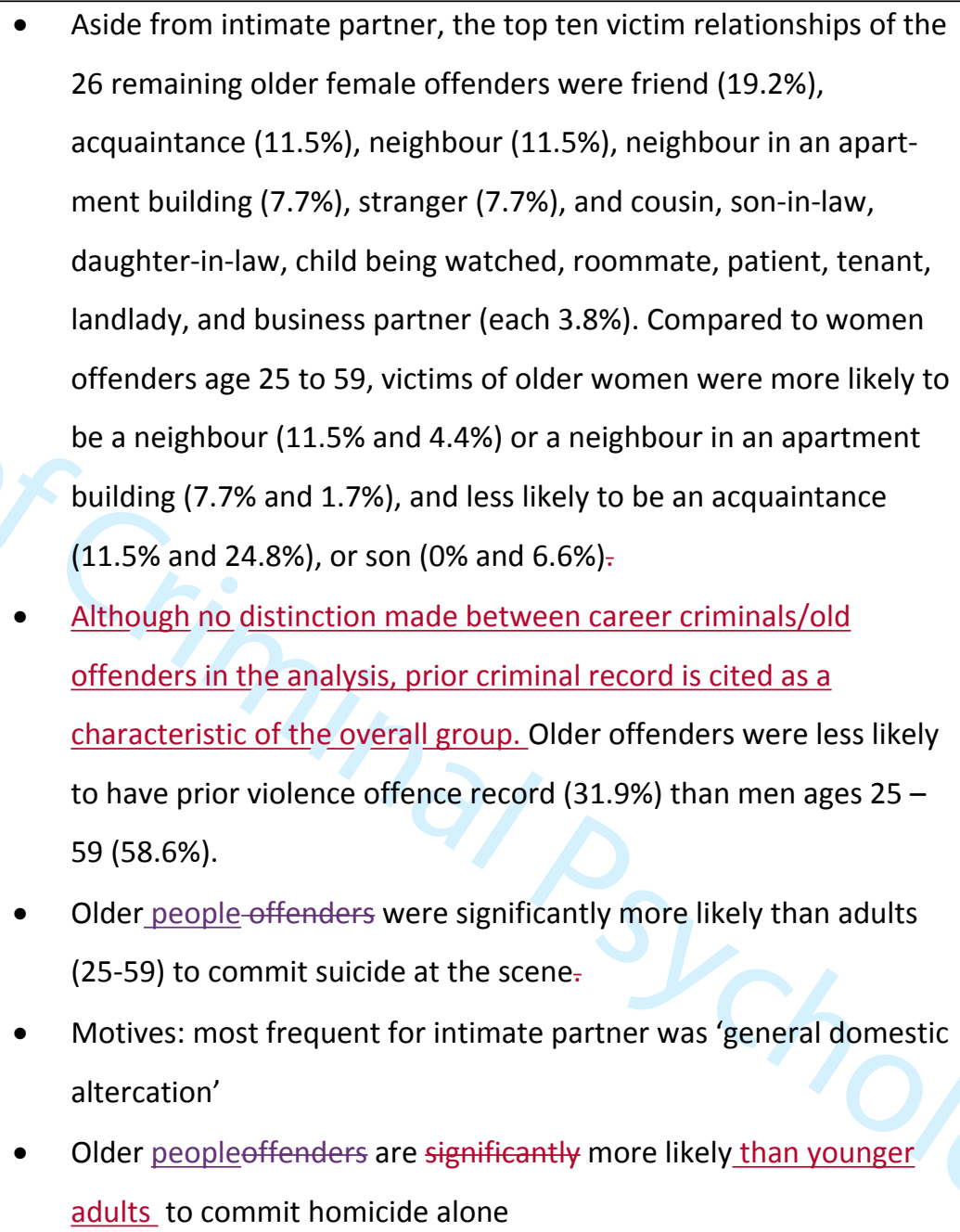 & \\
\hline Booth (2016) & $\begin{array}{l}\text { - } \quad \text { Review paper } \\
\text { - Older peopleindividuals who have } \\
\text { sexually offended }\end{array}$ & $\begin{array}{l}\text { This paper highlights older prisoners needs, health and psychiatric } \\
\text { health and issues with sex offender risk assessment. This paper } \\
\text { argues that the widely used RNR model focusses on criminogenic }\end{array}$ & $\begin{array}{l}\text { This paper highlights older prisoners needs, } \\
\text { health and psychiatric health and issues with } \\
\text { sex offender risk assessment. This paper }\end{array}$ \\
\hline
\end{tabular}




\begin{tabular}{|c|c|c|c|}
\hline & & $\begin{array}{l}\text { needs but does not include mental health needs relevant to an } \\
\text { older population (e.g. cognitive decline and hearing impairments). } \\
\text { This paper makes a case for the over measurement of risk in older } \\
\text { offenders, due to the lack of acknowledgement of the relationship } \\
\text { between age and testosterone decline, in relation to the } \\
\text { relationship between testosterone and sexual drive. } \\
\text { Notesd that individuals experience issues and difficulties solving } \\
\text { interpersonal situations; } 20 \% \text { referral rate for dementia in the older } \\
\text { population; undetected and prevalence of psychiatric disorder and } \\
\text { cognitive impairment; severe mental illness, of whom } 57 \% \text { had } \\
\text { depression, } 25 \% \text { had schizophrenia, and } 18 \% \text { had bipolar illness. }\end{array}$ & $\begin{array}{l}\text { argues that the widely used RNR (risk, needs, } \\
\text { responsivity) model focusses on criminogenic } \\
\text { needs but does not include mental health } \\
\text { needs relevant to an older population (e.g. } \\
\text { cognitive decline and hearing impairments). } \\
\text { This paper makes a case for the over } \\
\text { measurement of risk in older offenders, due to } \\
\text { the lack of acknowledgement of the } \\
\text { relationship between age and testosterone } \\
\text { decline, in relation to the relationship between } \\
\text { testosterone and sexual drive. }\end{array}$ \\
\hline $\begin{array}{l}\text { Centre for } \\
\text { Policy on Ageing } \\
\text { (2016) }\end{array}$ & $\begin{array}{l}\text { - Older prisoners - general review / } \\
\text { position paper } \\
\text { - Highlights trends based on } 2016 \\
\text { prison data of } 12,700 \text { older people } \\
\text { in prison (England and Wales) } \\
\text { Findings based on trends from } \\
\text { sSample of } 12,700 \\
\text { Older people (50+) } \\
\text { Male sample }\end{array}$ & $\begin{array}{l}\text { - Presents demographic data; confirmation of a general growth in } \\
\text { the older prison poptlation and nNotes that sexual offences and } \\
\text { violence against the person are higher in } 50+\text { male offenders than } \\
\text { younger offenders. } \\
\text { - Suggests that special needs of older prisoners include: social } \\
\text { exclusion /segregation; medication; release planning and end of life } \\
\text { care provision. }\end{array}$ & $\begin{array}{l}\text { This paper discussed the issues with the } \\
\text { prevalence of health care issues and the } \\
\text { complexity of prisons meeting the health care } \\
\text { needs of older prisoners. This paper suggests } \\
\text { that special needs of older prisoners include: } \\
\text { social exclusion/segregation; medication; } \\
\text { release planning and end of life care provision. }\end{array}$ \\
\hline $\begin{array}{l}\text { Chua, Cheung, } \\
\text { Friedman \& }\end{array}$ & $\begin{array}{l}\text { Systematic review } \\
\text { Findings based on collective }\end{array}$ & $\begin{array}{l}\text { The studies included in this review paper were summarised to highlight } \\
\text { the characteristics of first-time older sex offenders, } \text {-This review }\end{array}$ & $\begin{array}{l}\text { This review highlighted the lack of consistent } \\
\text { reporting of characteristics, demographics and }\end{array}$ \\
\hline
\end{tabular}




\begin{tabular}{|c|c|c|c|}
\hline Taylor (2018) & $\begin{array}{l}\text { Sample of } 26 \text { individuals } \\
\text { - Oof older people (65+) } \\
\text { - Firs' time oOlder individuals who } \\
\text { have committed sex offenscessex } \\
\text { effenders. (recent \& historic) } \\
\text { - First time offenders and repeat } \\
\text { - Thfenders } \\
\text { case report papers \& } 2 \\
\text { retrospective research studies) } \\
\text { with a total sample of } 26 \\
\text { individuals }\end{array}$ & $\begin{array}{l}\text { noteings that: } \\
\text { - Ffirst time older sex offender's victims are often vulnerable (either } \\
\text { minors or with intellectual disability). } \\
\text { - Lack of either screening or reporting with regards to psychological } \\
\text { and cognitive assessments of older offenders. In the few studies } \\
\text { where cognitive assessments had taken place they were not } \\
\text { elaborated on. } \\
\text { Physical disorder such as physical disability, chronic respiratory } \\
\text { failure, difficulties in verbal communication, ambulation (used a } \\
\text { wheelchair), and urinary incontinence were, similarly, reported in } \\
\text { few studies. } \\
\text { Psychiatric diagnosis was recorded in case reports: diagnosis } \\
\text { included dementia, depression, vascular dementia, Alzheimer's } \\
\text { disease, frontal lobe dysfunction and chronic schizophrenia. } \\
\text { The review discussed two types of older offenders (1) repeat } \\
\text { offenders but not detected until later life (2) late offenders } \\
\text { withwith a higher proportion of neurocognitive disorder. } \\
\text { The review highlights a lack of consistent recording and reporting of } \\
\text { characteristics and demographics and a need for better designed } \\
\text { studies. } \\
\text { The study notes the lack of either screening or reporting with regards } \\
\text { to psychological and cognitive assessments of older offenders. In the } \\
\text { few studies where cognitive assessments had taken place they were }\end{array}$ & $\begin{array}{l}\text { psychological assessments in the published } \\
\text { studies and case reports on older sex offenders. } \\
\text { The review suggests a lack of routine cognitive } \\
\text { and dementia assessments, either performed } \\
\text { or reported, specific to this population. } \\
\text { The review highlights a lack of consistent } \\
\text { recording and reporting of characteristics and } \\
\text { demographics and a need for better designed } \\
\text { studies. }\end{array}$ \\
\hline
\end{tabular}




\begin{tabular}{|c|c|c|c|}
\hline & & $\begin{array}{l}\text { not elaborated on. Physical disorder such as physical disability, chronic } \\
\text { respiratory failure, difficulties in verbal communication, ambulation } \\
\text { (used a wheelchair), and urinary incontinence were, similarly, reported } \\
\text { in few studies. Psychiatric diagnosis was recorded in case reports: } \\
\text { diagnosis included dementia, depression, vascular dementia, } \\
\text { Alzheimer's disease, frontal lobe dysfunction and chronic } \\
\text { schizophrenia. }\end{array}$ & \\
\hline $\begin{array}{l}\text { Curtice, Parker, } \\
\text { Wismayer \& } \\
\text { Tomison (2003) }\end{array}$ & $\begin{array}{l}\text { - } \quad \text { Based on 11-year survey of } \\
\text { referrals to regional forensic } \\
\text { psychiatric services } \\
\text { - } \quad \text { Sample of } 32 \text { case reviewss were } \\
\quad \underline{\text { reviewed. }} \\
\text { - } \quad \text { Older people-offenders }(65+) \\
\text { - } 31 \text { males and } 1 \text { female } \\
19 \text { were first time offenders } \\
32 \text { cases were reviewed. }\end{array}$ & $\begin{array}{l}\text { Found } 66 \% \text { of referrals came from solicitors.Sexual offending was } \\
\text { the most common index offence (56\%); violent offences ( } 25 \%) ; \\
\text { murder/manslaughter ( } 9 \% \text { ) and attempted arson (3\%) of cases. } \\
\text { Although no distinction made between career criminals/old } \\
\text { offenders in the analysis, prior criminal record is cited as a } \\
\text { characteristic of the overall group.The majority (59\%) were first } \\
\text { time offenders with no previous history. } \\
\text { There was no diagnosis of mental disorder in } 56 \% \text { of cases, } \\
\text { however, where there was a diagnosis, dementia was the most } \\
\text { common ( } 19 \% \text { ); depression (6\%); schizophrenia (6\%) mild learning } \\
\text { disability (3\%). This paper found poor use of diagnostic tools and } \\
\text { investigations in the assessment process. Alcohol history was } \\
\text { noted in } 79 \% \text { of cases, } 41 \% \text { of patients being regular users. } \\
\text { This paper suggests that an integrated approach to assessment and } \\
\text { management of older forensic populations is required. }\end{array}$ & $\begin{array}{l}\text { This paper argues for the focus on referrals to } \\
\text { medium secure forensic services in UK, with the } \\
\text { aim to review the complex needs and describe } \\
\text { the characteristics of older offenders. } \\
\text { This paper suggests that an integrated } \\
\text { approach to assessment and management of } \\
\text { older forensic populations is required. }\end{array}$ \\
\hline $\begin{array}{l}\text { Fazel \& Grann } \\
(2002)\end{array}$ & 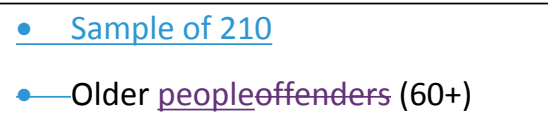 & $\begin{array}{l}\text { - There appear to be important differences in psychiatric morbidity } \\
\text { between older offenders and younger offenders who come into }\end{array}$ & $\begin{array}{l}\text { There appear to be important differences in } \\
\text { psychiatric morbidity between older offenders }\end{array}$ \\
\hline
\end{tabular}




\begin{tabular}{|c|c|c|c|}
\hline & $\begin{array}{l}\text { - } 16 \text { females and } 194 \text { males Sweden } \\
\text { - } \quad \text { F21 forensic psychiatric } \\
\text { evaluations } \\
\text { - } \quad \text { No distinction between career } \\
\text { criminals/old offenders }\end{array}$ & $\begin{array}{l}\text { contact with forensic psychiatric services. } \\
\text { illness; } 8 \% \text { depressive or anxiety disorder; } 15 \% \text { substance abuse or } \\
\text { dependence; } 20 \% \text { personality disorder. Older offenders were } \\
\text { significantly less likely than younger offenders to be diagnosed with } \\
\text { schizophrenia or personality disorder and more likely dementia or } \\
\text { affective psychosis. }\end{array}$ & $\begin{array}{l}\text { and younger offenders who come into contact } \\
\text { with forensic psychiatric services. This research } \\
\text { may assist in the planning of forensic and } \\
\text { therapeutic services for the increasing number } \\
\text { of older adults passing through the criminal } \\
\text { justice system. }\end{array}$ \\
\hline $\begin{array}{l}\text { Fazel, Hope, } \\
\text { O’Donnell \& } \\
\text { Jacoby (2002) }\end{array}$ & 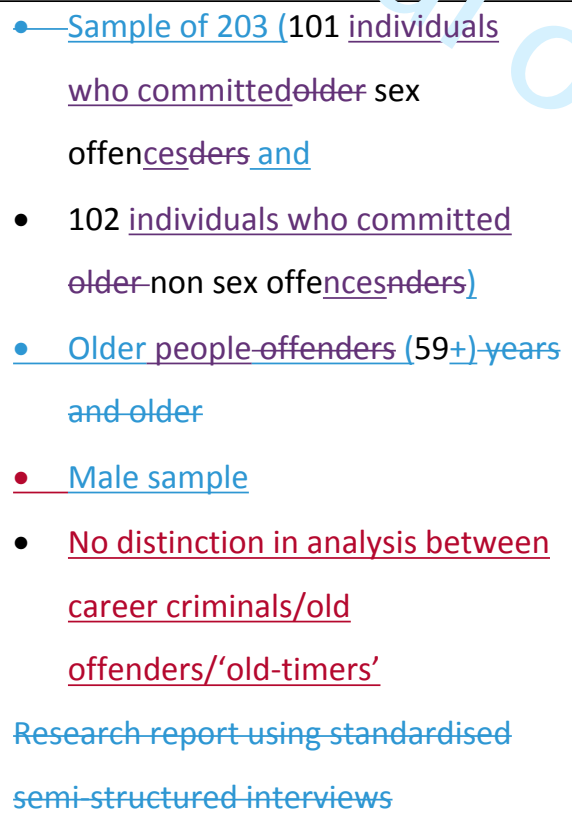 & $\begin{array}{l}\text { - Found } 6 \% \text { of older individuals who committed sex offensesders had } \\
\text { a psychotic illness; } 7 \% \text { major depressive episode; } 33 \% \text { personality } \\
\text { disorder; } 1 \% \text { dementia. -These figures did not significantly differ } \\
\text { from older non-sex offenders, }, \text { but d } \\
\text { - Differences occurred when considering personality traits - sex } \\
\text { offenders had more schizoid, obsessive-compulsive and avoidant } \\
\text { traits, and fewer antisocial traits compared with non-sex offenders. } \\
\text { Although no distinction was made between career criminals/old } \\
\text { offenders/'old-timers' in the analysis, median time spent in prison } \\
\text { was reviewed and not significantly different for those who had } \\
\text { committed sex offences compared with those who had not } \\
\text { committed sex offences. }\end{array}$ & $\begin{array}{l}\text { This paper focussed on demographics and } \\
\text { personality characteristics and discussed the } \\
\text { similar levels of mental illness across sex } \\
\text { offenders and non-sex offenders. However, } \\
\text { different personality traits were found across } \\
\text { these groups, suggesting that personality traits } \\
\text { were better related to offence type than } \\
\text { mental health concerns. }\end{array}$ \\
\hline $\begin{array}{l}\text { Fazel, } \\
\text { O'Donnell, } \\
\text { Hope, Gulati \& } \\
\text { Jacoby (2007) }\end{array}$ & $\begin{array}{l}\text { - Sample of } 100 \text { prisoners } \\
\text { - Oldersex peopleoffenders }(59+) \\
\text { - Male sample } \\
\text { - Sex and non-sex offence }\end{array}$ & $\begin{array}{l}\text { The mean age of the individuals who committed sex and non-se* } \\
\text { effenders crimes was similar (66 years [sd } 4.6 \text { ] vs } 64.9 \text { years [sd } 4.9] \\
\text { range } 60-88 \text { years). } \\
\text { - This paper found no evidence to support that older sex offender's }\end{array}$ & $\begin{array}{l}\text { This paper discussed, based on empirical } \\
\text { evidence, that there was no evidence to } \\
\text { support that older sex offender's frontal lobes } \\
\text { differ from older non-sex offender's frontal }\end{array}$ \\
\hline
\end{tabular}




\begin{tabular}{|c|c|c|c|}
\hline & $\begin{array}{l}\text { comparison } \\
\text { - No distinction in analysis between } \\
\text { car' } \text { er criminals/old } \\
\text { offenders/'old-timers'100 } \\
\text { prisoners were administered } \\
\text { frontallobe tests }\end{array}$ & $\begin{array}{l}\text { frontal lobes differ from older non-sex offender's frontal lobes. } \\
\text { There were no significant differences in test scores for frontal lobe } \\
\text { tasks between the two prisoner samples. } \\
\text { - There were no significant differences in socio-economic class, } \\
\text { although there was a trend for sex offenders to be from lower } \\
\text { socio-economic classes. 15\% of the total sample did not consent to } \\
\text { be interviewed, and the non-consenters were similar in age, type of } \\
\text { effence, ethnicity but had been in prison longer, than those whe } \\
\text { did consent. There were no significant differences in test scores for } \\
\text { frontallobe tasks between the two prisoner samples. } \\
\text { Although no distinction made between career criminals/old } \\
\text { offenders/'old-timers' in the analysis, median time spent in prison } \\
\text { was reviewed and not significantly different for those who had } \\
\text { committed sex offences compared with those who did not commit } \\
\text { sex offences. }\end{array}$ & tobes. \\
\hline $\begin{array}{l}\text { Feldmeyer \& } \\
\text { Steffensmeier } \\
\text { (2007) }\end{array}$ & $\begin{array}{l}\text { - Older people--ffenders }(55+) \\
\text { - Federal Bureau of Investigation } \\
\text { data - reports from uniformed } \\
\text { police officers } \\
\text { - Data was taken across different } \\
\text { years for comparison (e.g. 1980 = } \\
833 \text { arrests; } 1990=657 \text { arrests and } \\
2004=590 \text { arrests in } 55+) \\
\text { - No distinction in analysis between }\end{array}$ & $\begin{array}{l}\text { Looked at trends in older offender crime rates over } 25 \text { years } \\
\text { nNoteings that there has been very little change in the profile of } \\
\text { the older offender, with arrests continuing to be overwhelmingly } \\
\text { for minor offences and alcohol-related violations. } \\
\text { similar trends among the nonelderly, indicating that recent social, } \\
\text { economic, and legal changes have had similar impacts on arrest } \\
\text { patterns across age groups. }\end{array}$ & $\begin{array}{l}\text { This paper discussed in the trends in older } \\
\text { effender crime rates over past } 25 \text { years. } \\
\text { Generally, these remained the same for } \\
\text { uniform crime reports of arrests with primarily } \\
\text { minor and alcohol-related offences. }\end{array}$ \\
\hline
\end{tabular}




\begin{tabular}{|c|c|c|c|}
\hline & career criminals/old offenders & & \\
\hline $\begin{array}{l}\text { Greene \& } \\
\text { Gibson (2013) }\end{array}$ & $\begin{array}{l}\text { - Book chapter - review } \\
\text { - Old } r \text { peopleadults in the legal } \\
\text { system }\end{array}$ & $\begin{array}{l}\text { - Highlights that older people are the most increased offendef } \\
\text { population (up by 15.1\%) in the US compared to 18-44 (up by 0.6\%) } \\
\text { and under } 18 \text { (up by 2.6\%) in time period 2000-2010. Reports that } \\
\text { olderaging prisoners are far less likely to recidivate compared to } \\
\text { the younger population. } \\
\text { - Some key features for older individuals in prison are the } \\
\text { accelerating aging process; low levels of self-care; high psychiatric } \\
\text { conditions, social and emotional affects; victimisation; cut off } \\
\text { contact to reduce their suffering and negative self-reflection of } \\
\text { their lives. } \\
\text { Notes that older offenders present issues as diverse as: health care } \\
\text { needs; end-of-life care and decisions; social security, medication, } \\
\text { and Medicare entitlements; estate planning, wills, trusts, and } \\
\text { probate, cognitive impairment and guardianship, and elder abuse. }\end{array}$ & $\begin{array}{l}\text { This paper discusses that older people are } \\
\text { prevalent in the legal system and present issues } \\
\text { as diverse as health care needs; end-of-life care } \\
\text { and decisions; social security, medication, and } \\
\text { Aedicare entitlements; estate planning, wills, } \\
\text { trusts, and probate, cognitive impairment and } \\
\text { guardianship, and elder abuse. This paper } \\
\text { highlights the need for a focus on older } \\
\text { prisoner wellbeing; physical health and mental } \\
\text { health care. }\end{array}$ \\
\hline Gross (2007) & $\begin{array}{ll}\text { - } & \text { Book chapter - review } \\
\text { - Older peopleeffenders }(55+) \text { in the } \\
\text { legal system }\end{array}$ & $\begin{array}{l}\text { - Provides a summary of information older offenders in the USA from } \\
\text { 1971-2004. from 2000 2004. During the period 2000-2004 crime } \\
\text { by older people rose. is time period, } \\
\text { - violent crime arrests increased in both number (from 7251-te } \\
\text { 8,893) and proportion (1.8\% to 2.1\%) based on US data. The 55-64 } \\
\text { age group showed an increase in the number of violent, property, } \\
\text { and drug crime arrests during 2000-2004. Property crime arrests } \\
\text { remained the same. } \\
\text { Violent crime rate decreased slightly for those aged 65+, while }\end{array}$ & $\begin{array}{l}\text { This paper discussed the characteristics of older } \\
\text { offenders and typologies, data around older } \\
\text { arrestees and long-term prisoners, showing an } \\
\text { increase in the number of violent crime arrests. }\end{array}$ \\
\hline
\end{tabular}




\begin{tabular}{|c|c|c|c|}
\hline & & $\begin{array}{l}\text { property and drug crime rates remained relatively stable for this } \\
\text { age group. }\end{array}$ & \\
\hline $\begin{array}{l}\text { Hunt et al. } \\
\text { (2010) }\end{array}$ & $\begin{array}{l}\text { Sar ple of } 365 \\
\text { Older homicide perpetrators Oldef } \\
\text { peopleoffenders ( } 311 \text { were } 45-64+ \\
\text { and } 54 \text { wereaged } 65+\text { ). } \\
\text { - } 90 \% \text { were male and } 10 \% \text { were } \\
\text { female } \\
\text { - } 8 \text {-year period (1997-2004) } \\
\text { - Data from the National } \\
\text { Confidential Inquiry into Homicide } \\
\text { by people with Mental Illness } \\
\text { (Appleby et al., 1999) } \\
\text { No distinction in analysis between } \\
\text { career criminals/old offenders }\end{array}$ & $\begin{array}{l}\text { Highlights some key factors and characteristics of older perpetrators of } \\
\text { homicide, such as: } \\
\text { - Pperpetrators aged } 65 \text { and over were most likely to use } \\
\text { strangulation/suffocation and the victim was more often a female } \\
\text { and a family member or spouse. } \\
\text { - Older perpetrators had high rates of affective disorder and were } \\
\text { - more likely to be mentally ill at the time of the offence. } \\
\text { Of the } 54 \text { older perpetrators who killed a family member or spouse, } \\
\text { seven (13\%) were considered 'mercy killings'. } \\
\text { Although no distinction made between career criminals/old } \\
\text { offenders in the overall analysis, } 6 / 54 \text { of the } 65+\text { group and } 92 / 311 \\
\text { of the } 45-64 \text { group had a previous conviction for a violent offence. }\end{array}$ & $\begin{array}{l}\text { The results are consistent with American } \\
\text { Department of Justice and Australian Institute } \\
\text { of Criminology data with regards to } \\
\text { demographics and offence characteristics of } \\
\text { perpetrators. Older perpetrators were less } \\
\text { likely to have a history of violence and more } \\
\text { likely to target a female and a family member. } \\
\text { Also, more likely to have symptoms of mental } \\
\text { illness at the time of the offence. Preventing } \\
\text { homicide among older people might be best } \\
\text { achieved through more specialised GP training } \\
\text { to improve recognition and treatment of } \\
\text { depression. }\end{array}$ \\
\hline $\begin{array}{l}\text { Overshott et al. } \\
\text { (2012) }\end{array}$ & 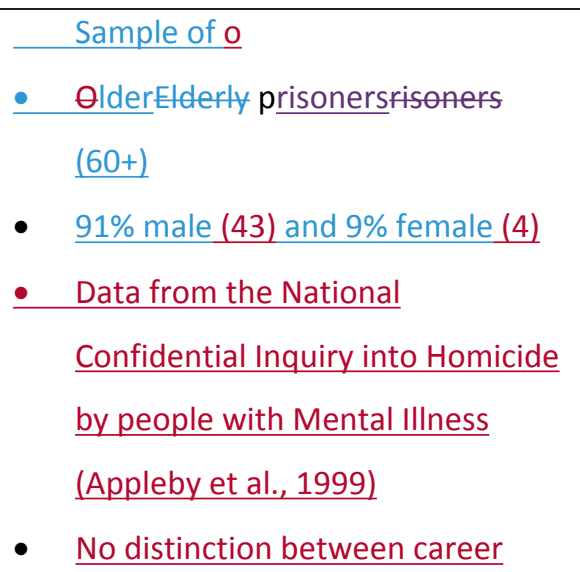 & $\begin{array}{l}\text { - The study was carried out as part of the Engtand and Wales } \\
\text { National Confidential Inquiry into Suicide and Homicide by-People } \\
\text { convicted of homicide were reported to the Inquiry. } 47 \text { Forty-seven } \\
\text { (2\%) of the perpetrators were aged } 60 \text { years or older; } 22 \text { of the } 47 \\
\text { (1\%)+were } 65 \text { years or older. } \\
\text { Homicide incidents perpetrated by older people typically involved a } \\
\text { man killing his partner in an impulsive manner. The most common } \\
\text { method was by using a sharp instrument (34\%), followed by the use }\end{array}$ & $\begin{array}{l}\text { The paper aims to describe the circumstances } \\
\text { in which older people commit homicide, } \\
\text { concluding that homicide incidents perpetrated } \\
\text { by older people typically involve a man killing } \\
\text { his partner in an impulsive manner. The paper } \\
\text { provides social, behavioural and offence } \\
\text { characteristics and discusses perpetrators with } \\
\text { psychiatric reports. The study highlights the } \\
\text { prominence of depression in older perpetrators }\end{array}$ \\
\hline
\end{tabular}




\begin{tabular}{|c|c|c|c|}
\hline & criminals/old offenders & $\begin{array}{l}\text { of a blunt instrument (26\%). The use of firearms was rare (11\%). } \\
\text { to kill a current or former spouse/partner and less likely to kill an } \\
\text { acquaintance. } \\
\text { - Ferpetrators aged } 65 \text { years and older were significantly more likely } \\
\text { depression at the time of the offence. } R \text {, whereas fates of } \\
\text { schizophrenia and alcohol dependence were low. }\end{array}$ & $\begin{array}{l}\text { of homicide, rather than the psychotic } \\
\text { disorders and alcohol/drug problems seen in } \\
\text { younger perpetrators. }\end{array}$ \\
\hline $\begin{array}{l}\text { Putkonen, } \\
\text { Weizmann- } \\
\text { Henelius, Repo- } \\
\text { Tiihonen, } \\
\text { Lindberg, } \\
\text { Saarela, Eronen } \\
\text { \& Häkkänen- } \\
\text { Nyholm (2010) }\end{array}$ & $\begin{array}{ll} & \text { Sample of } 25 \\
\text { Older homicide perpetrators } & \text { Prisonersprisoners }(60+) \\
\text { - } & \text { Three females and } 22 \text { males } \\
\text { - Homicide cases } \\
\text { - } \quad \text { AQuantitative analysis of large } \\
\text { national dataset from Finland } \\
\text { - Explores differences between } \\
\text { career criminals/old offenders }\end{array}$ & 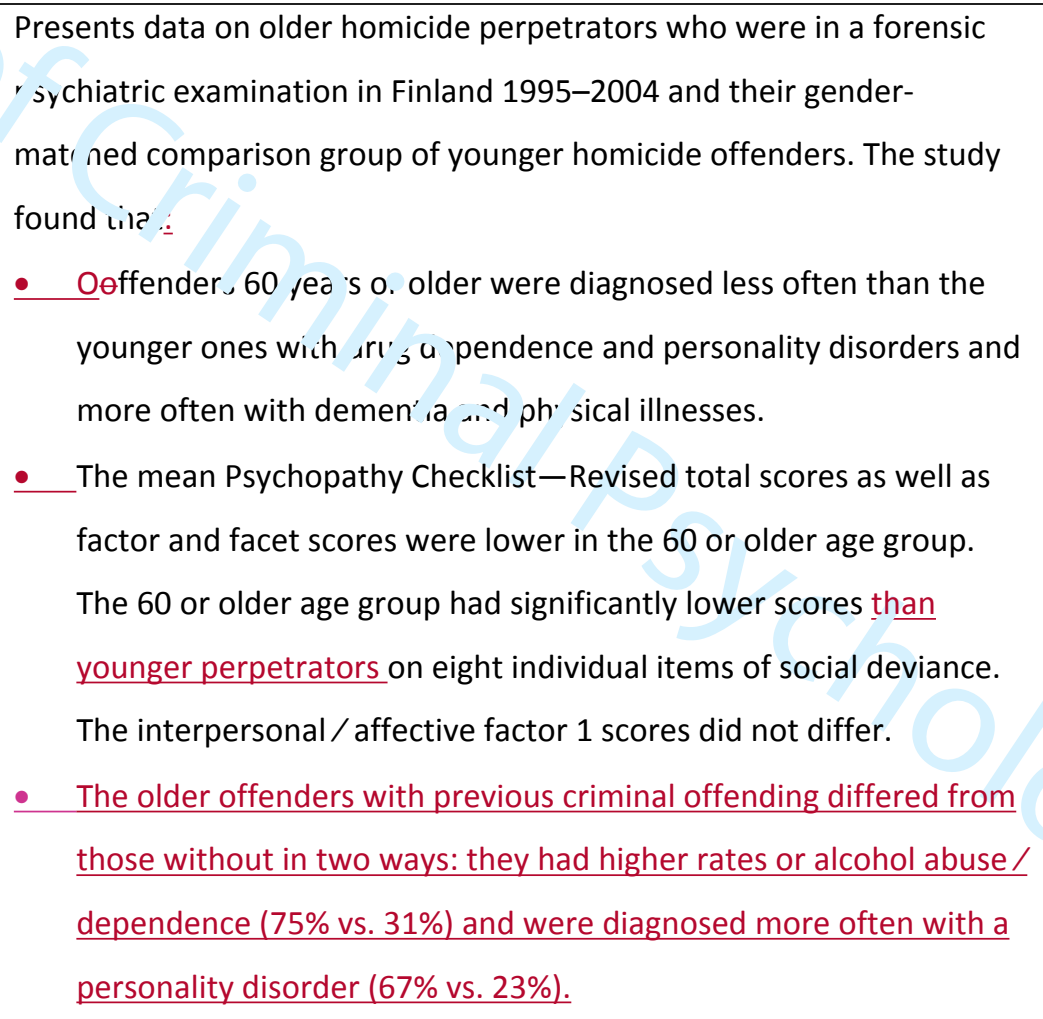 & $\begin{array}{l}\text { The paper suggests that there are age } \\
\text { differences in homicide offenders, with older } \\
\text { effenders scoring lower for psychopathy, but } \\
\text { having more dementia and/or physical illness } \\
\text { than younger offenders, and therefore } \\
\text { presenting different needs in prison. }\end{array}$ \\
\hline Reutens, & - Sample of 87 cases & Presents a systematic search of legal, criminological and media & The paper highlights the high number of \\
\hline
\end{tabular}




\begin{tabular}{|c|c|c|c|}
\hline $\begin{array}{l}\text { Nielssen \& } \\
\text { Large (2015) }\end{array}$ & 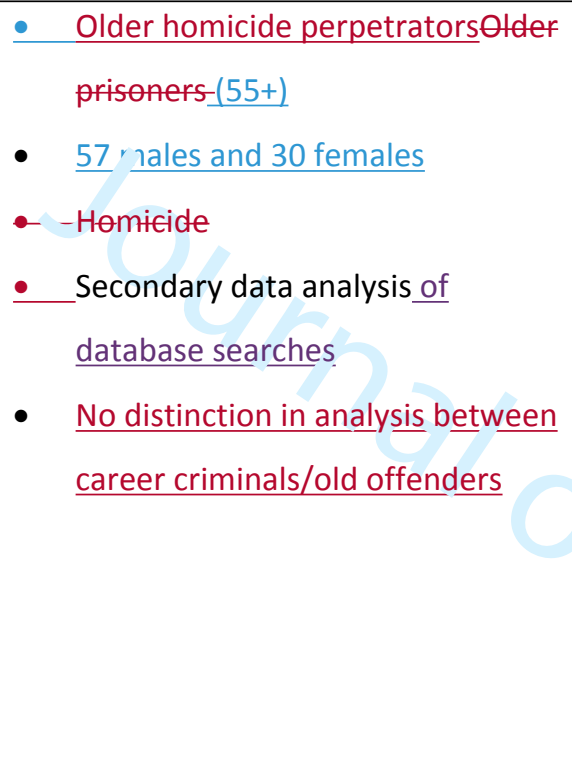 & $\begin{array}{l}\text { databases for cases of homicide committed by people aged } 55 \text { and over, } \\
\text { during the } 18 \text { years from } 1993 \text { to } 2010 . \\
\text { Eighty-seven cases were identified through databases. Legal documents } \\
\text { were obtained for } 70 \text { offenders (about } 5 \% \text { of homicides committed in } \\
\text { NSW in the period of the study). } \\
\text { - The proportions of male offenders and rates of firearm use were } \\
\text { similar to other age groups. Twelve of the } 14 \text { homicides using guns } \\
\text { occurred outside the metropolitan area. } \\
\text { OlderElderly offenders were more likely than younger perpetrators } \\
\text { o have cognitive impairment or psychotic illness. } \\
\text {-VIcti. is W. re more likely to be female and in a domestic } \\
\text { relationsh: }, \text { w: n i i c c.fender. }\end{array}$ & $\begin{array}{l}\text { physical health problems and high proportion } \\
\text { of individuals with cognitive impairments and } \\
\text { psychosis, compared to general (younger) } \\
\text { homicide perpetrators. }\end{array}$ \\
\hline $\begin{array}{l}\text { Rodriguez, } \\
\text { Boyce \& Hodges } \\
\text { (2017) }\end{array}$ & $\begin{array}{l}\text { - Sample of } 100 \text { (32 first time sex } \\
\text { offenders; } 36 \text { historic sex } \\
\text { offenders; } 32 \text { non sexual } \\
\text { offenders) } \\
\text { - Older people-offenders }(50+) \\
\text { - Male sample } \\
\text { - First time sex offenders } \\
\text { - Empirical study }\end{array}$ & $\begin{array}{l}\text { Presents the findings fr } m, \mathrm{wttery} \text { of neuropsychological measures } \\
\text { administered to } 100 \text { particip } n^{+}, 1^{2} \text { fi st time sex offenders; } 36 \text { historic } \\
\text { sex offenders; } 32 \text { non sexual offenders). } \\
\text { executive function (including verbal fluency, trail-making, and the } \\
\text { Hayling test of response inhibition) as well as on tests of verbal and } \\
\text { verbal memory compared to NSOs; } \\
\text { Thowever, there was no difference between the two sex offender } \\
\text { groups. }\end{array}$ & $\begin{array}{l}\text { Elderly sex offenders demonstrated poorer } \\
\text { neuropsychological performance } \\
\text { than elderly adult non-sex offenders did, } \\
\text { although there was no difference between } \\
\text { elderly first-time and historical offenders. } \\
\text { cognitive deficits may increase the risk of } \\
\text { sexual offending due to impaired capacity in } \\
\text { self-regulation, planning, judgment, and } \\
\text { inhibition. The authors suggest that proportion } \\
\text { of elderly adult sex offenders may be } \\
\text { harbouring acquired frontal lobe pathology. }\end{array}$ \\
\hline Stanback \& & - Sample of 972 & Presents analysis of the Chicago Homicide Dataset (1965-1995) and & While the study focuses primarily on victim \\
\hline
\end{tabular}




\begin{tabular}{|c|c|c|c|}
\hline $\begin{array}{l}\text { King-Kallimanis } \\
\text { (2011) }\end{array}$ & 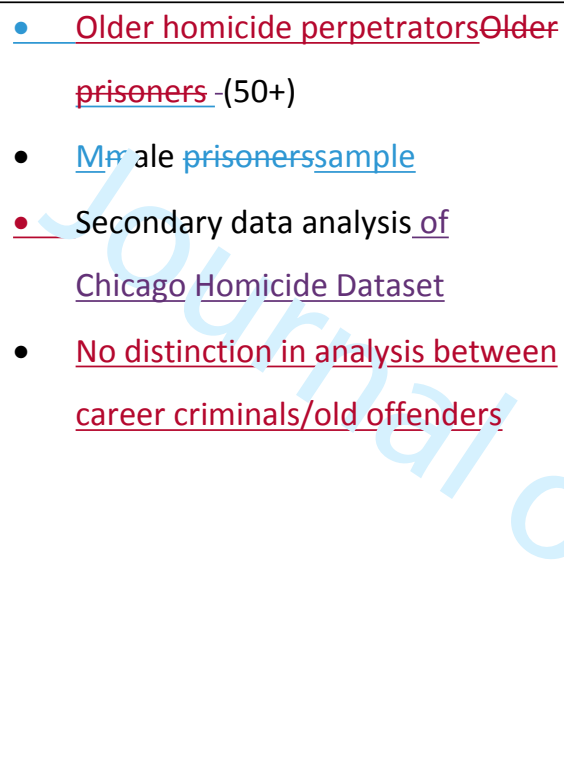 & $\begin{array}{l}\text { investigates covariates associated with four categories of homicide } \\
\text { committed by older offenders: intimate, family, acquaintance, and } \\
\text { unrelated victims. A multinomial multivariate regression, where } \\
\text { unrelated homicides were defined as the base outcome, The findings } \\
\text { reveal revealed that: } \\
\text { - in intimate and family comparisons, that women were at a } \\
\text { significantly higher risk of victimisation. } \\
\text { Crimes that occurred in residences were significantly associated } \\
\text { with all three homicides groups compared with unrelated } \\
\text { iomicides. } \\
\text { The } 1 \text {, e of alrohol was significant in crimes where an acquaintance } \\
\text { was the vi cim }\end{array}$ & $\begin{array}{l}\text { eharacteristics, the paper does highlight } \\
\text { interesting findings around interpersonal } \\
\text { relationship issues in intimate or family } \\
\text { homicide. This suggests a need to better } \\
\text { understand spousal relationships further, which } \\
\text { might be one important way to identify } \\
\text { households at risk of violence (for example, } \\
\text { stresses of late life, caregiver responsibilities). }\end{array}$ \\
\hline $\begin{array}{l}\text { Williams \& } \\
\text { Rikard (2005) }\end{array}$ & $\begin{array}{l}\text { - } \\
\text { Sample of } 51 \text { departments of } \\
\text { corrections } \\
\text { - Older womenpeopleoffenders } \\
\text { - } 455+) \\
\text { - Female sampleemale sample No } \\
\text { distinction in analysis between } \\
\text { career criminals/old } \\
\text { offenders/'old-timers' }\end{array}$ & $\begin{array}{l}\text { Explores policies ano pr gr } 4 \text { for older female prisoners. Interviews } \\
\text { were conducted with the Federal Bureau of Prisons and state } \\
\text { Department of Corrections ( } \mathrm{N}=40 / 51 \text { ) about their policies and } \\
\text { programs for older female prisoners. } \\
\text { r. While } 23 \text { States provided care for ageing male prisoners, only two } \\
\text { reported providing provision for older female prisoners. } \\
\text { mental health needs and it is important to highlight the gendered } \\
\text { needs of older prisoners. }\end{array}$ & $\begin{array}{l}\text { The authors highlight that the characteristics of } \\
\text { older female prisoners may mean they are } \\
\text { particularly low risk. However, they also posit } \\
\text { that the lack of provision amounts to neglect. } \\
\text { The discussion highlights that female prisoners } \\
\text { tend to have greater mental health needs and it } \\
\text { is important to highlight the gendered needs of } \\
\text { older prisoners. }\end{array}$ \\
\hline Yorston (2010) & $\begin{array}{ll}\text { - } & \text { Older prisoners } \\
\text { - } & \text { titerature-Rfeview paper }\end{array}$ & $\begin{array}{l}\text { Primarily focuses on the characteristics of older effendersprisoners. The } \\
\text { paper highlights that: }\end{array}$ & $\begin{array}{l}\text { The paper outlines some of the key } \\
\text { characteristics and areas where more research }\end{array}$ \\
\hline
\end{tabular}




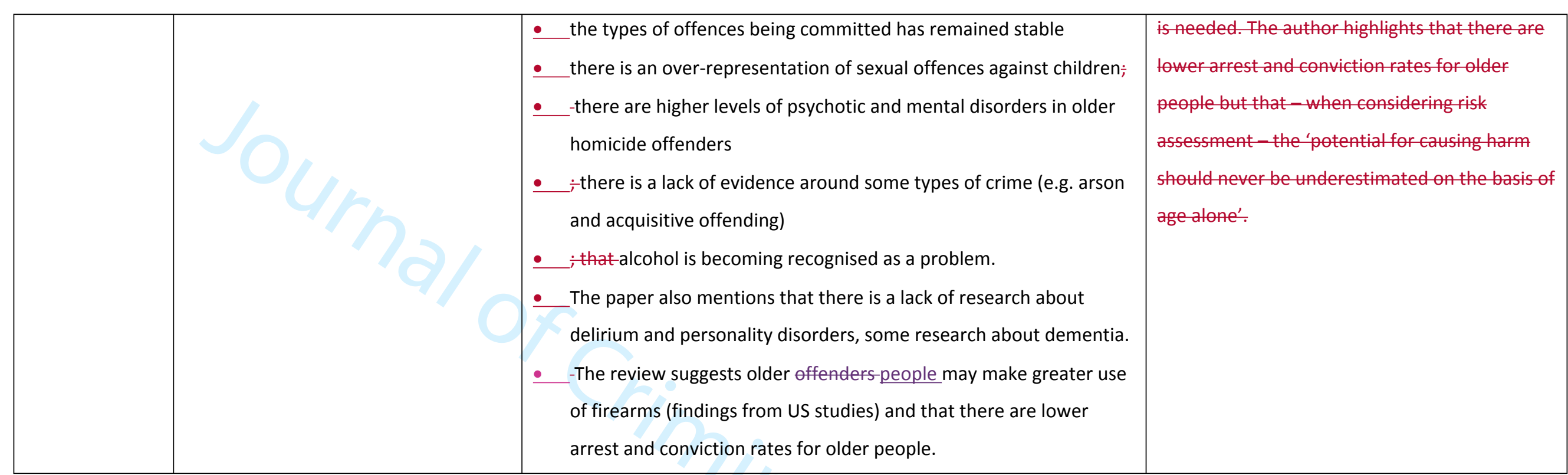




\subsection{SummaryDiscussion of results and concluding discussion}

The population focus of the papers was as follows: General older prisoners, seven papers; Female older prisoners, one paper; Psychiatric evaluated older prisoners, two papers; Older sex offenders, five papers; Older homicide offenders, six papers (see table 1.0 for the breakdown). Thematic summaries of these papers are presented below, under these headings.

\subsection{General}

Four of the seven papers considered within this category were review papers. The papers that presented new research findingseonsidered the general older prisoner population included data outlining the types of offences committed by this group. -Beaufrère et al. (2014) found physical assaults were the main suspected crime in their sample of 180 older suspects in France. For example, Tthe Centre for Policy on Ageing (2016) noted that violent crimes remained consistent across all age groups for male offenders in the UK (under 25; 25-49; 50-59; 60+)= As a proportion of effences committed by each age group, however, while the proportion of sexual offences were highest in older offenders (accounted for $13 \%$ of $25-49$ year olds $s_{\bar{i}} 34 \%$ of $50-59$ year olds; $\&$, and $59 \%$ of $60+$ those over age 60 . The types of offence committed by female offenders remained relatively stablethe same across age groups (Centre for Policy on Ageing, 2016).

SWhile some studies note the relatively stable nature of offending by older people. fFeldmeyer and \& Steffensmeier $(-2007)$ for example found very little change in the profile of the older offender, with arrests mainly for minor offences and alcohol-related violations. However, the most recent data in that study is now 15 years old.; Yorston, 2010), Similarly, Yorston's (2010) review paper suggests that the types of offences being committed by older people have remained stable. However, cEontradictions appear in the literature-evidence base. For example, while Feldmeyer and Steffensmeier report most known offending by older people being minor, in the same year and in the same country (USA) Gross (2007) reported increased violent crime in this group.. Gross' (2007) review paper, for example, notes an increase in other research has documented an increase in some types of offending (e.g.violent crime among older people. While contradictions appear, both,Gross 2007). Feldmeyer and Steffensmeier (2007) and Yorston (2010) highlighted the increased recognition of the role of alcohol in offences committed by older peoplebase. For example, while Feldmeyer and Steffensmeier report most knownoffending by oldef people being minor, in the same year and in the samecountry (USA)Gross (2007) reported

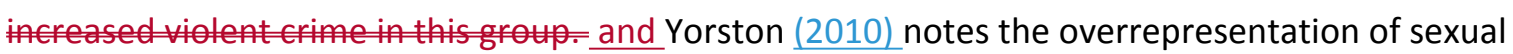
offences committed by older offenders. 
A number of pPapers included in this review discuss the stress the importance of the-health-are needs of this population, given the prevalence of current health problems compared to younger offenders and the increased support required for daily tasks such as bathing (Beaufrere et al., 2014; Eentre for Policy on Ageing, 2016; Greene \& Gibson, 2013). This-includinges physical health issues as well as psychiatric and psychological health concerns (Beaufrère et al., 2014; Centre for Policy on Ageing, 2016; Greene \& Gibson, 2013; Yorston, 2010). The prison environment is designed for young and able-bodied people (Baidawi et al., 2011) and older adults are often not willing or able to participate in correctional, criminal, or probation programmes (Greene and Gibson, 2013). The rise in numbers of older prisoners makes it difficult to ignore the needs of this population. The potential vulnerability and victimisation of older prisoners is also noted in some studies (Centre for Policy on Ageing, 2016; Baidawi et al., 2011). However, Yorston (2010, p695) notes that 'the potential for causing harm should never be underestimated on the basis of age alone' Yorston (2010), however, highlights that - when considering risk assessment - the 'potential for causing harm should never be underestimated on the basis of age alone' ( $p$ 695).

The research in this section presents agreement over the existence of physical and mental health needs in the older offender population, but there is a lack of consistency in terms of the reported offending patterns of this group. The various methodologies employed (e.g. some presents a $\underline{s}$ snapshot in time, other comparisons over time, others comparisons against other age groups) make comparison between studies difficult. Baidawi et al makes the case that defining the 'older prisoner' is essential in order to do comparative research and a lack of clarity can impede a firm evidence base being formed around related issues, for example, offence types, recidivism rates, health concerns and prison management programs. The data presented in these empirical and review studies is sometimes based on small sample sizes (e.g. Beaufrère et al., (2014), varied in methodology, and typically fails to make a clear distinction between career criminals/old offenders.

\subsection{Female}

Williams and Rikard (2005) conducted the only study found through this systematic review to focus solely on older female prisoners. While their research focused on policies and programs, Williams and Rickard (2005) highlight that the characteristics of older female prisoners may mean they are particularly low risk, but that there is a need to take account of gender-specific needs. For example, women in contact with the criminal justice system have particularly high levels of need around mental health (Caulfield, 2016). Baidawi et al. (2014), in their review paper, note the likely complexity of 'minority' groups, including women. Furthermore, as noted above, the over- 


\subsection{Psychiatric}

Curtice et al. (2003) found that of the 32 cases of older offenders referred to a regional psychology service in the UK, sexual offending was the most common offence. Dementia was a common diagnosis in the cases reviewed (19\%). In a review of the psychiatric evaluations of 210 older offenders, Fazel and Grann (2002, also UK) found that this group were less likely to be diagnosed with a mental health condition (including schizophrenia and personality disorders) than younger offenders, but more likely than then general offending population to be diagnosed with dementia or affective psychosis. Yorston et al., (2010) notes homicide followed by suicide is more common in older adults than younger homicide perpetrators. These findings suggest important differences in the psychiatric and cognitive needs of older and younger prisoners, which should be investigated further - and if more widely applicable - taken into account when planning provision for older prisoners. Yorston et al., (2010) notes homicide followed by suicide is more common in older adults. However, the limited recent published literature available on the needs of this group means more systematic research is needed in this area.

\subsection{Sex Offenders}

In his review of research on older sex offenders, Booth (2016: 5) states that 'when faced with an older sexual offender, the index of suspicion for cognitive issues should be high', although he notes that the general risk level presented by this group may be lower than younger sex offenders. Fazel et al. (2002) report similarly high levels of mental health problems and neurocognitive disorders among 
older sex offenders and older non-sex offenders. However, they do note differences in personality traits, with older sex offenders having higher rates of schizoid, obsessive-compulsive, and avoidant traits, and fewer antisocial traits. As part of the same wider study, Later work by Fazel et al. (2007) administered frontal lobe tests to older sex offenders and older non-sex offenders, finding no significant frontal lobe differences between the two groups. The only notable difference between the groups was the average lower socio-economic status of the sex offender group. The latter sample is likely to be subset of the former (although this is not explicitly stated in the paper). Chua et al.'s (2018) systematic review-papef of older first time sex offenders reports a range of sexual offence types, some historic and some current/on-going, and a higher incidence of neurocognitive disorders than found in younger offenders. They report a high incidence of victims with mental illness and/or developmental disorders, with most victims being children or older people. However, despite being a systematic review paper, the overall sample considered in the paper is very small (26 individuals). Rodriquez et al.s (2017) sample of first time and historic older sex offenders demonstrated poorer neuropsychological performance than older non-sex offenders did, although there was no difference between the older first-time and historical offenders. Cognitive deficits may increase the risk of sexual offending due to impaired capacity in selfregulation, planning, judgment, and inhibition. The authors suggest that proportion of elderly adult sex offenders may be harbouring acquired frontal lobe pathology. However, the sample size of 100 in this study limits generalisability. Fazel et al (2007) suggest that other possible risk factors for sexual offending, such as psychosocial -and criminal history, might be areas for future research.

\subsection{Homicide}

Block (2013) looked at homicide cases-committed by older offenders, finding that-male older offenders were more likely than younger offenders to have killed an intimate partner. Reutens et al. (2015) also found that the victims of older homicide perpetrators were likely to be female and in a domestic relationship with the offender.-Older offenders in Block'stheir sample were less likely than younger offenders to have a history of violence, more likely to commit the homicide alone, and the most frequent motive was noted as 'general domestic altercation'. Stanback and King-Kallimanis (2011)'s work suggests a need to better understand spousal relationships, which might be one important way to identify households at risk of violence (for example, stresses of late life, caregiver responsibilities). Research by Hunt et al. (2010) and Overshot et al. (2012) add support to this, finding that homicide victims of older perpetrators are likely to be a female family members or spouse. Both studies also found high rates of perpetrator mental illness at the time of the offence, 
particularly depression. In Reutens et al.'s study older offenders were more likely than younger perpetrators to have cognitive impairment or psychotic illness. Overshot et al. (2012) found low rates of schizophrenia and alcohol dependence than seen in younger homicide perpetrators. Hunt at al.(2010) suggest there is a need for improved recognition and treatment of mental illness in older people, and posit that preventing homicide among older people might be best achieved through more specialised GP training to improve recognition and treatment of depression.- The existing research, however, underlines the complexities with Overshot et al. (2012) finding lower rates of schizophrenia and alcohol dependence than seen in younger homicide perpetrators. Putkonen et al. (2010) present data on older homicide perpetrators in forensic psychiatric examination. They reporting lower levels of drug dependence and personality disorders, and lower scores of the Psychopathy Checklist, than younger perpetrators (data on older homicide perpetrators in forensic psychiatric examination).: However, Putkonen et al. and perhaps unsurprisingly, they found higher rates of dementia and physical illness.

\subsubsection{SummaryEonclusions}

The aim of this paper was to systematically search the literature to select and review all existing and relevant studies that have explored the needs and characteristics of older prisoners. After a thorough search and selection process 21 papers, from 2002 onwards, were included in the final analysis. These papers came from the United Kingdom, Australia, France, the USA, Canada, New Zealand, Sweden, Japan, and Finland.

The contradictions within the existing evidence base make it difficult to reach firm conclusions about the needs and characteristics of older offenders. For example, some papers present older offending patterns as relatively stable over time while others suggest there have been increases in certain types of crime committed by older people (e.g. violent crime). There is, however, some consensus regarding older people who have committed certain types of offences. For example, where older people commit homicide the victim is likely to be an intimate partner.

What is clearer from the existing research are the relatively high levels of need in this group. However, inconsistencies in the existing research again underline the complexities of reaching firm conclusions, with some agreement about higher incidences of cognitive impairment - particularly in certain sub-groups of older offenders - but differences where mental health is concerned. Where research does exist on needs and characteristics, this primarily relates to older men and very little is known about older women in contact with the criminal justice system. Given the gendered nature of 
needs of younger adults in the criminal justice system (Caulfield, 2010) and that there are physical differences in the way men and women age (menopause, for example, is briefly discussed in Public Health England guidance on gender specific guidance for improving health and wellbeing in prisons in England: PHE, Peden et al., 2018), this is an important area for future consideration. How offending patterns and needs relate to risk and risk assessment is a point without any clear consensus.

Any conclusions drawn from the existing literature should be taken with caution. There are a relatively small number of recent papers focused on the needs and characteristics of older people in contact with the criminal justice system, and sample sizes are generally small (overall, and even smaller when broken down into sub-categories of older offenders). Furthermore, when reviewing existing studies if it not possible to compare like for like. There are various methodologies employed with some studies presenting a snapshot in time, others making comparisons over time, and others making comparisons against other age groups, making comparison between studies difficult. In this current systematic review we included older people in contact with the criminal justice system broadly to avoid missing important learning, but this is a further example of an inability to compare like for like. The existing research also often fails to make clear distinctions between groups of older prisoners, such as whether individuals are career criminals (prison recidivists), old offenders (first incarcerated age 55 or older), first offenders (first incarcerated before the age of 55), or 'old-timers' (growing old in prison) (Goetting, 1984). For example, Block (2013) identifies prior criminal history as one potential characteristic of those perpetrating crime at age $60+$, but does not break down her analysis to look at the separate characteristics of old offenders vs. recidivists.

Overall, there is a lack of consistent recording and reporting of characteristics and demographics and - as Chua et al. (2018) note in their review of the characteristics of first time older sexual offenders a need for better designed, more systematic studies. Perhaps even more basic a start-point, Baidawi et al (2011) make the case that defining the 'older prisoner' consistently is essential in order to do comparative research.

\section{$\underline{4.7 \text { Conclusion }}$}

Overall, 21 papers presented reviews of or research on the characteristics of older prisoners. These papers came from the United Kingdom, Australia, France, the USA, Canada, New Zealand, Sweden, tapan, and Finland. 
The prison population is ageing, and this is an international issue, yet there remains a lack of consistency about how older prisoners are defined and understood. The papers reviewed here suggest that older prisoners have significant needs, and therefore present challenges, around physical and mental health in a system primarily design for young men. In particular, dementia and eognitive decline appear prevalent in some groups of older prisoners. Some of these needs are also characteristics related to the types of offences common in older prisoners. For example, there is evidence to suggest a link between mental health problems in older individuals and violent offending, and that the victims of these crimes are often spouses or other close family members of the offenderbut evidence about the prevalence of needs and their relationship to factors such as offence type, is mixed. Much of this is because the approach to the existing research has not been consistent.

A better understanding of these patterns and precipitators would enable an evidence-based conversation about prevention. In addition, dementia and cognitive decline has been found at a relatively high rate in older sex offenders. If we acknowledge, for example, that the prison environment - or certainly most current, typical prison environments - is likely to increase the speed of cognitive decline, and this may be an issue with some sub-groups of older prisoners, there are important questions here about both need and risk. Indeed, there has been an assumption that the risk presented by older prisoners may be lower than younger sex offenders, despite their victims typically being vulnerable groups (children and\& elderly, Chua et al. 2018). Many studies also considerinclude prisoners who have grown old in prison alongsidewith those who have entered prison at a late age (for current or historic offences). It would be useful to look at the different factors relevant to these groups. The literature to date has also been almost exclusively focused on the older male prison population, while older women have been almost entirely excluded from the literature.

What is clear from this systematic review is that there is a lack of clear understanding about the characteristics of older prisoners as a whole, despite this being an international issue. A wealth of information exists in our criminal justice, correctional, and government systems about prisoners, their characteristics, their need and risk, their history, and the judicial decisions surrounding their cases. Future research should make use of these data sources to provide a much clearer understanding of this group, their routes to prison, their needs, and the challenges they present. A better and coordinated understanding of the reasons behind the significant increase in the older population in prison could: a) guide the development of regimes that are less reactive and support the specific needs of older offenders, including the need for meaningful activities while in prison (Hayes, Burns, Turnbull, and Shaw, 2013; NACRO, 2009; Wilkinson \& Caulfield, 2017); b) allow for 
fuller consideration of the risk profile of this group; and c) provide evidence to support the development of appropriate assessment and treatment. Increased understanding of this group and the precipitating factors surrounding their offence may not only provide lessons for better supporting those convicted and reducing their needs and risk, but also may provide lessons for the prevention of such crimes. 


\section{References}

Aday, R. H., \& Krabill, J. J. (201ㄹz). Older and geriatric offenders: Critical issues for the 21st century. In L. Gideon (ed.), Special needs offenders in correctional institutions (pp.,-203-232).

Thousand Oaks, CA: Sage Publications.

Allen, R. (2015). Global prison trends 2015. Penal Reform International https://cdn.penalreform.org/wp-content/uploads/2015/04/PRI-Prisons-global-trends-report-LR.pdf

Baidawi, S., Trotter, C., \& Flynn, C. (2016). Prison experiences and psychological distress among older inmates. Journal of gerontological social work, $\underline{59}(3), 252-270$.

Baidawi, S., Turner, S., Trotter, C., Browning, C., Collier, P., O'Connor, D., \& Sheehan, R. (2011). Older prisoners-A challenge for Australian corrections. Trends and issues in crime and criminal justice,

(426), 1. https://www.scopus.com/inward/record.uri?eid=2-

$\underline{\text { s2.080054026363\&partnerID=40\&md5=eda631617d71d695d5340dab9cc1c9ab }}$

Beaufrère, A., Belmenouar, O., \& Chariot, P. (2014). Elderly arrestees in police custody cells:

implementation of detention and medical decision on fitness to be detained, Forensic Science

International, 241, 15-19. Retrieved from

https://search.proquest.com/docview/1545300280?accountid=14685

Block, C. R. (2013). Homicide Against or by the Elderly in Chicago 1965-2000. Homicide Studies, 17(2), 154-183. https://doi.org/10.1177/1088767913478596

Booth, B. D. (2016). Elderly Sexual Offenders. Current Psychiatry Reports, 18(4), 1-7.

https://doi.org/10.1007/s11920-016-0678-1

Bureau of Corrections and Philippine Statistics Authority (2015). 2015 Philippines statistics yearbook.

Quezon City: Philippine Statistics Authority.

Bureau of Justice Statistics. Prisoners Series: 1990-2010. Washington, DC: Department of Justice, Office of Justice Programs, Bureau of Justice Statistics. Available at http://bjs.ojp.usdoj.gov/index.cfm?ty=pbse\&sid=40 Accessed June 2016.

Canada, K. E., Barrenger, S. L., Robinson, E. L., Washington, K. T., \& Mills, T. (2019). A systematic review of interventions for older adults living in jails and prisons. Aging \& mental health, 1-9.

Carabellese, F., Candelli, C., Vinci, F., Tamma, M. and Catanesi, R. (2012) Elderly Sexual Offenders:

Two Unusual Cases. Journal of Forensic Sciences, 57, 1381 1383. https://doi.org/10.1111/i.1556$\underline{4029.2012 .02129 . x}$

Caulfield, L.S. (2016). Counterintuitive findings from a qualitative study of mental health in English women's prisons. International Journal of Prisoner Health, 12 (4), 216-229.

Centre for Policy on Ageing (2016). Diversity in older age: older offenders. London: Centre for Policy on Ageing. Retrieved from http://www.ageuk.org.uk/Documents/EN-GB/For-

professionals/Policy/equality-and- 
rights/CPA rapid review Diversity in older age Older Offenders.pdf?epslanguage=en-

\section{GB?dtrk=true}

Chua, J., Cheung, G., Friedman, S. H., \& Taylor, S. (2018). What are the characteristics of first time older sexual offenders? International Psychogeriatrics, 30(5), 647-662.

https://doi.org/10.1017/S1041610217002186

Curtice, M., Parker, J., Wismayer, F. S., \& Tomison, A. (2003). The elderly offender: An 11-year survey of referrals to a regional forensic psychiatric service. Journal of Forensic Psychiatry \& Psychology, 14(2), 253-265. https://doi.org/10.1080/1478994031000077989

Davis, B., Maclagan, M., \& Shenk, D. (2016). The silent violence of marginalization and teasing in dementia care residences. Journal of Language Aggression and Conflict, 4(1), 35-61.

Fazel, S., \& Grann, M. (2002). Older criminals: A descriptive study of psychiatrically examined offenders in Sweden. International Journal of Geriatric Psychiatry, 17(10), 907-913. https://doi.org/10.1002/gps.715

Fazel, S., Hope, T., O’Donnell, I., \& Jacoby, R. (2002). Psychiatric, demographic and personality characteristics of elderly sex offenders. Psychological Medicine, 32(2), 219-226.

https://doi.org/10.1017/\$0033291701005153

Fazel, S., O’Donnell, I., Hope, T., Gulati, G., \& Jacoby, R. (2007). Frontal lobes and older sex offenders: A preliminary investigation. International Journal of Geriatric Psychiatry, 22(1), 87-89. https://doi.org/10.1002/gps.1648

Federal Bureau of Prisons (2019). United States Department of Justice: Federal Prison System performance budget. Washington, DC: Federal Bureau of Prisons Feldmeyer, B. and Steffensmeier, D. (2007) Elder Crime: Patterns and Current Trends, 1980-2004. Research on Aging, 29, 297-322. https://doi.org/10.1177/0164027507300802 Gal, M. (2003). The physical and mental health of older offenders. Mental Health, 38, 17-2. Goetting, A. (1984). 'The elderly in prison: a profile', Criminal Justice Review, 9, 14-24. Greene, E., \& Gibson, S. C. (2013). The Experiences of Older Adults in the Legal System. In M. Miller and B. Bornstein, Stress, Trauma, and Wellbeing in the Legal System. University of ColoradoColorado_Springs_-_United States, Oxford Scholarship Online. https://doi.org/10.1093/acprof:0so/9780199829996.003.0007 Gross, B. (2007). Elderly offenders: Implications for corrections personnel. The Forensic Examiner, 16(1), 56-61. Retrieved from http://search.ebscohost.com/login.aspx?direct=true\&AuthType=ip, shib,cpid\&custid=s6264444\&db= psyh\&AN=2007-04268-005\&site=ehost-live \&scope=site 
Hayes, A. J., Burns, A., Turnbull, P., \& Shaw, J. J. (2013). Social and custodial needs of older adults in prison. Age and ageing, 42(5), 589-593.

Howse, K. (2011). Gorwing older in prison: A scoping study on older prisoners. Centre for Policy on Ageing and Prison Reform Trust.

Hunt, I. M., Swinson, A. B. N., Flynn, S., Hayes, A. J., Roscoe, A., Rodway, C., ... Shaw, J. (2010). Homicide convictions in different age-groups: A national clinical survey. Journal of Forensic Psychiatry and Psychology, 21(3), 321-335. https://doi.org/10.1080/14789940903513195 Ishihara, J., \& Kempf-Leonard, K. (2009). Exploring factors affecting the aging prison population in Japan. ProQuest Dissertations and Theses. Southern Illinois University at Carbondale, Ann Arbor. Retrieved from https://search.proquest.com/docview/304996355?accountid=14685

Kerbs, J. J., \& Jolley, J. M. (2007). Inmate-on-inmate victimization among older male prisoners. Crime \& Delinquency, 53(2), 187-218.

Kingston, P., Le Mesurier, N., Yorston, G., Wardle, S., \& Heath, L. (2011). Psychiatric morbidity in older prisoners: unrecognized and undertreated. International Psychogeriatrics, 23(8), 1354-1360.

Lemieux, C. M., Dyeson, T. B., \& Castiglione, B. (2002). Revisiting the literature on prisoners who are older: Are we wiser?. The Prison Journal, 82(4), 440-458.

Loeb, S. J., Steffensmeier, D., \& Kassab, C. (2011). Predictors of self-efficacy and self-rated health for older male inmates. Journal of advanced nursing, 67(4), 811-820.

Merten, M. J., Bishop, A. J., \& Williams, A. L. (2012). Prisoner health and valuation of life, loneliness, and depressed mood. American journal of health behavior, 36(2), 275-288.

Ministry of Justice (2018). Offender management statistics quarterly: January to March 2018. London: Ministry of Justice.

Ministry of Justice, Statistics Bureau of Japan (2016). Annual Report of Statistics on Corrections (2016). Tokyo: Ministry of Justice http://hakusyo1.moj.go.jp/en/66/nfm/n $66 \quad 2 \quad 24413 . h t m l$ Munday, D (2017) Health and social care needs assessments of the older prison population. London: Public Health England.

NACRO (2009). Foreign national offenders, mental health and the criminal justice system. London: NACRO.

Naikakufu (2009). Shōshika shakai hakusho (Heisei 21-nen ban) [(2009) white book on low fertility]. Tokyo: Naikakufu.

O'ㅂhara, K., Forsyth, K., Webb, R., Senior, J., Hayes, A. J., Challis, D., ... \& Shaw, J. (2016). Links between depressive symptoms and unmet health and social care needs among older prisoners. Age and ageing, 45(1), 158-163. 
Overshott, R., Rodway, C., Roscoe, A., Flynn, S., Hunt, I. M., Swinson, N., ... Shaw, J. (2012). Homicide perpetrated by older people. International Journal of Geriatric Psychiatry, 27(11), 1099-1105. Retrieved from http://search.ebscohost.com/login.aspx?direct=true \&db=pbh\&AN=82212127\&site=ehost-live Peden, J., McCann, L. O'Moore, E., Phipps, E., Ford, T., Plugge, ... Connolly, A.M. (2018). Gender Specific Standards to Improve Health and Wellbeing for Women in Prison in England. Public Health England https://assets.publishing.service.gov.uk/government/uploads/system/uploads/attachment data/file/687146/Gender specific standards for women in prison to improve health and wellb eing.pdf

Petersen, D. (1988) Substance Abuse, Criminal Behavior, and Older People. Journal of the American Society on Aging, 12, 63-67.

Prison Reform Trust (2019). Bromley briefings prison factfile: Winter 2019. London. Prison Reform Trust (2008). Doing Time: the experiences and needs of older people in prison. $A$ Prison Reform Trust briefing.

Prison Reform Trust (2018). Prison: the facts. Bromley briefings: Ssummer 2018. London. Putkonen, H., Weizmann-Henelius, G., Repo-Tiihonen, E., Lindberg, N., Saarela, T., Eronen, M. and Hakkanen-Nyholm, H. (2010). Homicide, psychopathy, and aging - a nationwide register-based casecomparison study of homicide offenders aged 60 years or older. Journal of Forensic Sciences, 55, 1552-1556. https://doi.org/10.1111/j.1556-4029.2010.01488.x

Reutens, S., Nielssen, O., \& Large, M. (2015). Homicides by older offenders in New South Wales between 1993 and 2010. Australasian Psychiatry, 23(5), 493-495.

https://doi.org/10.1177/1039856215579525

Rodriguez, M., Boyce, P., \& Hodges, J. (2017). A neuropsychological study of older adult first-time sex offenders. Neurocase (Psychology Press), 23(2), 154-161.

https://doi.org/10.1080/13554794.2017.1334802

Stanback, B., \& King-Kallimanis, B. L. (2011). Older offenders and homicide: What can we learn from the Chicago Homicide Dataset? Homicide Studies: An Interdisciplinary \& International Journal, 15(1), 32-47. https://doi.org/10.1177/1088767910397272

Stevens, B. A., Shaw, R., Bewert, P., Salt, M., Alexander, R., \& Loo Gee, B. (2018). Systematic review of aged care interventions for older prisoners. Australasian journal on ageing, 37(1), 34-42.

Trotter, C., \& Baidawi, S. (2015). Older prisoners: Challenges for inmates and prison management. Australian \& New Zealand Journal of Criminology, 48(2), 200-218. Whittemore, R., \& Knafl, K. (2005). The integrative review: updated methodology. Journal of advanced nursing, 52(5), 546-553. 
Wilkinson, D. J., \& Caulfield, L. S. (2017). The perceived benefits of an arts project for health and wellbeing of older offenders. Europe's journal of psychology, 13(1), 16.

Williams, B. A., Goodwin, J. S., Baillargeon, J., Ahalt, C., \& Walter, L. C. (2012). Addressing the aging crisis in US criminal justice health care. Journal of the American Geriatrics Society, 60(6), 1150-1156. Williams, M. E., \& Rikard, R. V. (2005). Marginality or neglect: An exploratory study of policies and programs for aging female inmates. Women and Criminal Justice, 15(3-4), 121-141.

https://doi.org/10.1300/J012v15n03 06

Wong, M.T., Lumsden, J., Fenton, G.W. and Fenwick, P.B. (1995). Elderly Offenders in a MaximumSecurity Mental Hospital. Aggressive Behavior, 21, 321-324. https://doi.org/10.1002/1098-2337 Yorston, G. A. (2010). The Elderly Offender. In Principles and Practice of Geriatric Psychiatry: Third Edition (pp. 694-699). St Andrew's Hospital, Northampton NN1 5DG, United Kingdom.

https://doi.org/10.1002/9780470669600.ch110 
Appendix A List of databases searched and results

\begin{tabular}{|c|c|c|}
\hline CINAHL complete & $1992-2018$ & 196 \\
\hline Cochran Library & $2001-2016$ & 14 \\
\hline ERIC & $1967-2018$ & 62 \\
\hline Europe PubMed Central & $2014-2018$ & 68 \\
\hline MEDLIN: & $1948-2018$ & 46 \\
\hline PsycARTICLI S & $1934-2018$ & 12 \\
\hline PsycINFO & $1923-2018$ & 159 \\
\hline SAGE Complete $A-\bar{Z}$ LIst & $1924-2018$ & 181 \\
\hline$\overline{\text { ScienceDirect Journals }}$ & $1995-2018$ & 561 \\
\hline Scopus & $2010-2019$ & 380 \\
\hline ProQuest Central & & 366 \\
\hline Web of Science & $1948-2018$ & 78 \\
\hline Social Care online & $1996-2016$ & 74 \\
\hline CINAHL Plus with Full Text & $\begin{array}{l}\text { Nu sing ar,d allied health journals } \\
\left.1992-?^{\prime}\right\lrcorner \perp \varnothing\end{array}$ & 199 \\
\hline Medline with full text & $\begin{array}{l}\text { Medicine ar } 九 \text { 'ealthcare } \\
\text { 1948-2018 }\end{array}$ & 306 \\
\hline $\begin{array}{l}\text { Psychology and Behavioral } \\
\text { Sciences Collection }\end{array}$ & $\begin{array}{l}\text { Emotional and } r \text {-na oural characteristics. } \\
\text { 1971-2018 }\end{array}$ & 91 \\
\hline SocINDEX with Full Text & $\begin{array}{l}\text { Sociological research } \\
1975-2017\end{array}$ & 67 \\
\hline Cambridge core & $\begin{array}{l}\text { Digitised backfiles of Science, } \overline{T e c n n o l o g y} \text { and Medicine } \\
\text { journals, and Humanities \& Soc. } 11 \text { jcir nces journals from } \\
\text { Cambridge University Press }\end{array}$ & 1 \\
\hline JSTOR & $\begin{array}{l}\text { JSTOR is a digital library of academic journals, books, and } \\
\text { primary sources. JSTOR helps people discover, use, and } \\
\text { build upon a wide range of content through a powerful } \\
\text { research and teaching platform, and preserves this } \\
\text { content for future generations. }\end{array}$ & 9 \\
\hline PubMed & $\begin{array}{l}\text { biomedical literature from MEDLINE, life science journals, } \\
\text { and online books }\end{array}$ & 34 \\
\hline ProQuest & $\begin{array}{l}\text { A broad range of full-text and bibliographic databases } \\
\text { hosted by Proquest } \\
\text { Included: Dissertations and theses; Scholarly journals; } \\
\text { Books; Working papers; Trade journals }\end{array}$ & 463 \\
\hline Zetoc & The British Library's Electronic Table of Contents. & 16 \\
\hline
\end{tabular}


Journal of Criminal Psychology

Page 74 of 75

$$
\begin{aligned}
& 1 \\
& 2 \\
& 3 \\
& 4 \\
& 5 \\
& 6 \\
& 7 \\
& 8 \\
& 9 \\
& 10 \\
& 11 \\
& 12 \\
& 13 \\
& 14 \\
& 15 \\
& 16 \\
& 17 \\
& 18 \\
& 19 \\
& 20 \\
& 21 \\
& 22 \\
& 23 \\
& 24 \\
& 25 \\
& 26 \\
& 27 \\
& 28 \\
& 29 \\
& 30 \\
& 31 \\
& 32 \\
& 33 \\
& 34 \\
& 35 \\
& 36 \\
& 37 \\
& 38 \\
& 39 \\
& 40 \\
& 41 \\
& 42 \\
& 43 \\
& 44 \\
& 45 \\
& 46 \\
& 47 \\
& 48 \\
& 49 \\
& 50 \\
& 51 \\
& 52 \\
& 53 \\
& 54 \\
& 55 \\
& 56 \\
& 57 \\
& 58 \\
& 59
\end{aligned}
$$


Appendix B Search Strings Used in Literature Searches

\begin{tabular}{|c|c|c|c|}
\hline & Search Topic & Search Terms ${ }^{a}$ & $\begin{array}{l}\text { Search } \\
\text { Field }\end{array}$ \\
\hline 1 & Older Offe .der & $\begin{array}{l}\text { Older offender OR Elderly Offender OR Older prisoner OR Elderly Prisoner OR } \\
\text { Aging Prisoners OR Aging Offenders OR Geriatric offender OR Geriatric } \\
\text { prisoner OR Prisoner over AGE OR Offender over AGE } \\
\text { "Jlder offender" OR "Elderly Offender" OR "Older prisoner" OR "Elderly } \\
\text { P. ، רer" OR "Aging Prisoners" OR "Aging Offenders" OR "Geriatric offender" } \\
\text { Or. "Geı 'atric prisoner" OR "Prisoner over AGE" OR "Offender over AGE" }\end{array}$ & All text \\
\hline 2 & Health & Health OR Well-being OR Psycholog* OR Psyc* & All text \\
\hline 3 & Violence & $\begin{array}{l}\text { Violen* OR Aggressive OR Domestic OR intimate partner violence OR } \\
\text { Deviance OR Antisocial }\end{array}$ & All text \\
\hline 4 & Needs & Criminogenic Needs OR supportive needs & All text \\
\hline 5 & Risk? & $\begin{array}{l}\text { Risk assessment OR Crime committed OR Offence type (sub-search terms } \\
\text { needed??) Or Violence OR Violent offence Or Sexual offence OR First offence } \\
\text { OR First timer }\end{array}$ & All text \\
\hline 6 & $\begin{array}{l}\text { Offender } \\
\text { typology }\end{array}$ & Life course persistent? OR First-time older OR Repeat offender OR & All text \\
\hline 7 & $\begin{array}{l}\text { Intervention or } \\
\text { cause }\end{array}$ & $\begin{array}{l}\text { Characteristics OR Dementia OR Mental health (under 'causes' rather than } \\
\text { needs) OR Mental illness OR Ageing population OR Growing old OR Longer } \\
\text { sentences OR Indeterminate sentence OR Historic }\end{array}$ & All text \\
\hline
\end{tabular}




\section{Appendix C - PRISMA}

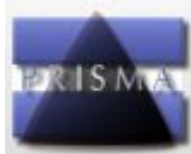

\section{Amended PRISMA 2009 Flow Diagram}

Records identified through database searching entered into Mendeley

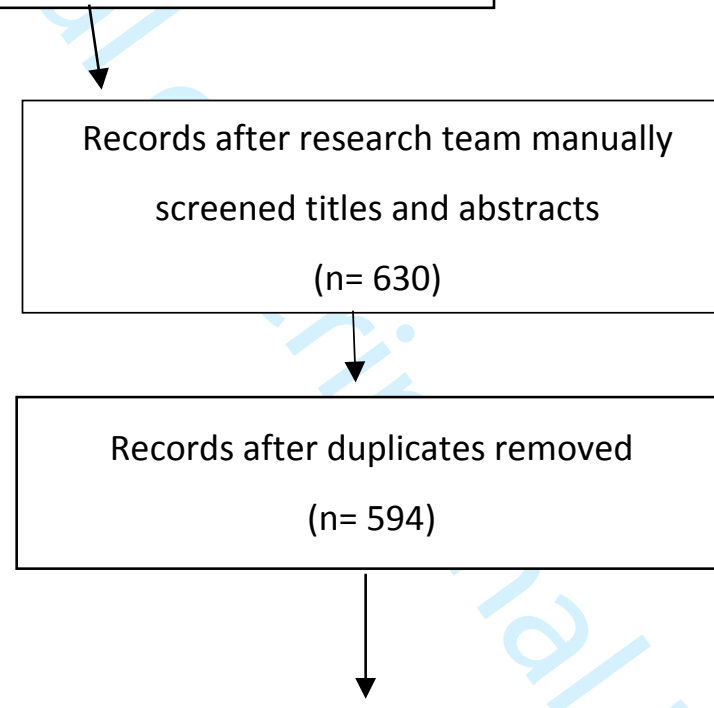

Full-text articles assessed for eligibility with inclusion and exclusion criteria

$$
(n=594)
$$

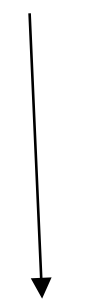

Studies included in synthesis

$$
(n=21)
$$

Records excluded ( $n=3258)$ manual screening to remove papers without Older Offender terms in title,
Full-text articles excluded, with

$$
\begin{aligned}
& \text { reasons } \\
& (n=566)
\end{aligned}
$$

Book reviews ( $n=12)$

Tender document $(n=2)$

Publication date prior to 2001

$$
(n=146)
$$

Physical health focussed $(n=406)$

Focus solely on the reasons behind the rise in the older offender population with no reference to the characteristics $(n=7)$ 